\author{
UNIVERSIDADE DE SÃO PAULO \\ FACULDADE DE FILOSOFIA, LETRAS E CIÊNCIAS HUMANAS \\ DEPARTAMENTO DE CIÊNCIA POLÍTICA \\ PROGRAMA DE PÓS-GRADUAÇÃO EM CIÊNCIA POLÍTICA
}

\author{
Érica Cruz e Silva
}

Atuação do empresariado brasileiro no governo Lula: o posicionamento da CNI sobre questões internacionais

São Paulo 


\author{
UNIVERSIDADE DE SÃO PAULO \\ FACULDADE DE FILOSOFIA, LETRAS E CIÊNCIAS HUMANAS \\ DEPARTAMENTO DE CIÊNCIA POLÍTICA \\ PROGRAMA DE PÓS-GRADUAÇÃO EM CIÊNCIA POLÍTICA
}

\title{
Atuação do empresariado brasileiro no governo Lula: o posicionamento da CNI sobre questões internacionais
}

\author{
Érica Cruz e Silva
}

Dissertação apresentada ao Programa de PósGraduação em Ciência Política do Departamento de Ciência Política da Faculdade de Filosofia, Letras e Ciências Humanas da Universidade de São Paulo, para obtenção do título de Mestre em Ciência Política.

Orientadora: Profa. Dra. Janina Onuki

São Paulo 


\section{ATUAÇÃO DO EMPRESARIADO BRASILEIRO NO GOVERNO LULA: O POSICIONAMENTO DA CNI SOBRE QUESTÕES INTERNACIONAIS}

Dissertação apresentada ao Programa de PósGraduação em Ciência Política do Departamento de Ciência Política da Faculdade de Filosofia, Letras e Ciências Humanas da Universidade de São Paulo, para obtenção do título de Mestre em Ciência Política.

Orientadora: Profa. Dra. Janina Onuki

Titulação: Mestre em Ciência Política

Banca Examinadora:

Prof. Dra. Janina Onuki (presidente)

Prof. Dr. Amâncio Jorge S. N. de Oliveira (DCP-USP)

Profa. Dra. Maria Antonieta Del Tedesco Lins (IRI-USP)

São Paulo 


\section{AGRADECIMENTOS}

Em primeiro lugar, sou grata a minha orientadora Profa. Janina Onuki por todo o auxílio na realização desta pesquisa e pela contribuição no meu amadurecimento enquanto pesquisadora desde a graduação. Obrigada pelas observações sempre precisas e essenciais e pela acessibilidade e presteza.

Agradeço aos professores Amâncio de Oliveira e Adriana Schor pelas contribuições preciosas e fundamentais para o desenvolvimento deste trabalho feitas no Exame de Qualificação. Agradeço, também, aos professores Amâncio e Maria Antonieta Del Tedesco Lins por aceitarem ser parte da minha Banca Examinadora.

Agradeço ao professor Matthew Macleod Taylor por fazer comentários e sugestões referentes ao início desta pesquisa.

Muito obrigada, em especial, à estimada amiga Marília por todo apoio e amizade fundamentais para o cumprimento de toda a trajetória do mestrado e ao estímulo para o desenvolvimento desta dissertação. Sua competência e brilhantismo serviram de exemplo e incentivo ao longo desse período.

Aos meus queridos pais Marcos Antônio da Silva e Marilena Rodrigues Cruz e Silva, meus sinceros agradecimentos por todo incentivo para desenvolver esta pesquisa e pelo suporte material. Agradeço também ao meu irmão Leandro pela amizade e ao meu tio Paulo pela prontidão e ajuda valiosa para a conclusão deste trabalho.

Obrigada aos professores e a toda equipe de funcionários da USP, pela constante ajuda e dedicação e aos colegas da turma de mestrado pelas discussões acadêmicas e pelos momentos de descontração.

Também sou grata aos queridos amigos Aline, Hyury, Patrícia, Rosi, Lúcia, Andréa, Linda e Sandra pelo apoio e convivência no período do mestrado.

Finalmente, agradeço, com todo apreço, a Rodrigo Coelho Marchiori pelo companheirismo, compreensão, carinho e torcida. 


\title{
RESUMO
}

Esta dissertação visa compreender a participação do setor empresarial nas negociações internacionais do Brasil. Para isso, será analisado o posicionamento do setor referente às negociações do Mercosul, Organização Mundial do Comércio e Mercosul-União Européia, enfocando nas posições da Confederação Nacional da Indústria (CNI) emitidas em documentos e declarações à imprensa no período 2003-2010. No debate da relevância do empresariado como ator político, os resultados da pesquisa buscam identificar se ocorreram mudanças no papel do setor no período do governo Lula em termos de representação e participação nas negociações internacionais, com recorte no balanço da evolução do posicionamento e da influência da CNI nessas negociações.

Palavras-chave: empresariado; Confederação Nacional da Indústria; negociações internacionais.

\begin{abstract}
This dissertation aims to understand the entrepreneurial sector participation in international negotiations of Brazil. For this, the dissertation will analyse the sector's position on the negotiations of Mercosur, the WTO and Mercosur-European Union, focusing on the positions of the National Confederation of Industry (CNI) issued in documents and statements to the press in the period 2003-2010. In discussing the importance of entrepreneurs as a political actor, the search results try to identify whether there were changes in the role of the sector in the period of Lula's government in terms of representation and participation in international negotiations, with clipping on the balance of the CNI's positioning and influence in those negotiations.
\end{abstract}

Key-words: entrepreneurs, National Confederation of Industry; international negotiations. 


\section{SUMÁRIO}

$\begin{array}{ll}\text { INTRODUÇÃO } & 06\end{array}$

CAPÍTULO 1 - Evolução da representação empresarial no Brasil 10

2.1 - Os Padrões Corporativo e extra-Corporativo de representação 11

$\mathbf{2 . 2}$ - Visões da literatura sobre o comportamento empresarial 17

CAPÍTULO 2 - Contribuições da CNI para a classe empresarial 22

CAPÍTULO 3 - Governo Lula: mudanças de enfoque na política externa

CAPÍTULO 4 - Posicionamento e evolução da participação empresarial nas questões internacionais do governo Lula 33

4.1 - Posicionamento da CNI sobre as negociações do Mercosul (2003-2010) 33

$\mathbf{4 . 2}$ - Posicionamento da CNI sobre as negociações na OMC (2003 -2010) $\mathbf{4 5}$

4.3 - Posicionamento da CNI sobre as negociações Mercosul-União Européia 56 (2003-2010)

CONCLUSÃO

REFERÊNCIAS BIBLIOGRÁFICAS

TABELAS

Tabela 1 - Conselhos Temáticos da CNI 24

Tabela 2 - Documentos e Relatórios da CEB sobre as negociações da OMC 49

ANEXO A - Processo de consulta à Indústria $\quad 71$ 


\section{INTRODUÇÃO}

Há décadas existe um amplo debate na literatura acadêmica acerca do papel do empresariado brasileiro como ator político, tema cuja agenda de pesquisa é vasta e incita novos estudos. A questão central do debate está enraizada em dois pólos distintos: parte da literatura caracteriza o empresariado como um ator político forte e outra parte o concebe como um ator político fraco ${ }^{1}$. Os estudos apontam que a existência ou ausência de uma entidade de representação de cúpula é um fator chave na análise da ação política desse setor. Este trabalho, inserido na discussão sobre o estudo do papel de atores nãogovernamentais na política externa brasileira, procura contribuir especificamente para a compreensão do posicionamento do empresariado nacional em relação às negociações internacionais do Brasil no período dos governos de Luis Inácio Lula da Silva (2003-2010).

A escolha deste período se deve a diversos fatores. Dentre eles, ao fato de que existe um relativo consenso entre os pesquisadores sobre o redirecionamento da política externa brasileira para novas estratégias internacionais, com diversificação das relações comerciais e ampliação das parcerias bilaterais e em várias organizações internacionais.

Ao mesmo tempo em que se buscou uma política comercial mais ativa, houve um esforço para ampliar espaço e criar condições para uma política industrial afirmativa. Assim, foi alargada a preocupação com a incorporação política do setor produtivo e com a expansão de canais de diálogo através de fóruns de negociação, visando atender às demandas de diferentes setores empresariais em torno de uma política industrial pautada por uma inserção mais autônoma do país no mercado internacional (BOSCHI; DINIZ, 2007).

No novo padrão de inserção internacional, o governo Lula priorizou a cooperação Sul-Sul, com o objetivo de aumentar o equilíbrio com os países desenvolvidos, ampliando também o protagonismo internacional do Brasil. O país reforçou o interesse nas negociações Mercosul-União Européia e atuou com destaque na Rodada Doha da Organização Mundial do Comércio (OMC), assim como em outras negociações

\footnotetext{
${ }^{1}$ Entende-se por força política, aqui, a capacidade de influenciar o processo de tomada de decisões do poder governamental, trazendo benefícios para o desenvolvimento e atuação da classe empresarial do país (MANCUSO, 2007).
} 
econômicas. O Brasil fez um grande arco de alianças, destacando-se a formação do G-20 e do IBAS (Índia, Brasil e África do Sul) (VIGENANI; CEPALUNI, 2007).

O Mercado Comum do Sul (Mercosul) foi mantido como prioridade estratégica durante o governo Lula. Embora entraves tenham se avolumado, sobretudo no que se refere à resistência de alguns setores produtivos brasileiros prejudicados pela concorrência e falta de políticas de desenvolvimento regional que buscassem maior equilíbrio e financiamento das cadeias produtivas dos países envolvidos, a integração do Mercosul foi ampliada com outras iniciativas de ampliação, como a Unasul.

Em suma, é certo que houve ênfase na ampliação das relações internacionais do Brasil no governo Lula, de modo que as negociações nos âmbitos da OMC, Mercosul e Mercosul-União Européia tiveram importância nesse processo.

Destarte, a dissertação buscará fazer o mapeamento da atuação do empresariado nacional acerca das negociações internacionais do Brasil no período 2003-2010, através da análise do posicionamento da Confederação Nacional da Indústria (CNI) sobre essas três arenas de negociação internacional.

A partir desse objetivo principal passaremos pelas seguintes questões: o empresariado industrial, na década de 2000, teve um papel protagonista ou teve pouca participação política? O setor conseguiu influenciar os processos decisórios das questões internacionais? Qual foi a importância da CNI neste período?

A escolha da CNI para a análise deu-se por sua importância na trajetória da indústria nacional. No passado, a entidade atuou na condução - junto ao Estado -, de diferentes políticas públicas para a criação e ampliação de uma estrutura industrial vasta e relativamente diversificada, que ocorreu dos anos 30 até o final dos anos 70, de modo que a consolidação da Confederação Nacional da Indústria acompanhou a do parque industrial brasileiro. $\mathrm{Na}$ atualidade, a entidade confederativa é um ponto de referência para as relações entre organizações empresariais, sobretudo para o diálogo empresarial na formação de objetivos de modernização econômica do país, competitividade industrial e ampliação da inserção internacional da indústria brasileira.

Sabe-se da limitação da CNI como representante do empresariado nacional na sua totalidade, já que a entidade é representante e porta-voz de interesses específicos das organizações industriais privadas em relação à política externa brasileira. Assim sendo, 
neste trabalho, tomaremos a CNI como uma entidade institucionalizada que pondera as posições heterogêneas do empresariado. Feita essa ressalva, em termos de nomenclatura, utilizaremos a expressão 'posicionamento da CNI' como sinônimo de posicionamento da classe empresarial privada.

Para a realização da pesquisa, a fonte de dados utilizada envolveu, em primeiro lugar, publicações, working papers, documentos de posicionamento, boletins, documentos de manifestações, documentos de recomendações, relatórios e notas técnicas produzidos pela CNI acerca dos processos de negociação internacionais abordados; em segundo, foram utilizados como fonte de dados, artigos e notícias sobre o posicionamento do empresariado divulgados pela imprensa (jornais e revistas) ${ }^{2}$, sobretudo as declarações emitidas por representantes da CNI e noticiadas pela imprensa.

A partir da coleta desse material, buscou-se perceber o posicionamento do setor empresarial em relação às negociações internacionais nos âmbitos da OMC, Mercosul e Mercosul-União Européia - assim como a evolução e alterações desse posicionamento no período 2003-2010 -, em diversas etapas e acontecimentos dos processos de negociação. Nesta pesquisa, não pretendo aclarar as negociações passo a passo, mas capturar seus pontos principais e examinar sua condução e resultados em linhas gerais, enfocando nas questões que suscitaram manifestações por parte da CNI e seus representantes.

Esta dissertação é composta por esta introdução e quatro capítulos. No primeiro capítulo, sintetizo o desenvolvimento da representação empresarial no Brasil desde a década de 1930 até o fim da década de 1990. Apresento também, no mesmo capítulo, as distintas visões da literatura acerca da capacidade de ação organizada da classe empresarial, demonstrando que, se até o fim da década de 1980 era consenso que o setor não tinha entidade de representação de cúpula multissetorial organizada, a partir da década de 1990, essa condição se altera; no segundo capítulo, procuro expor as principais contribuições da CNI para a classe empresarial e para a indústria brasileira, bem como mostrar sua estrutura interna e o modo como se organiza. No terceiro capítulo, abordarei brevemente as mudanças político-econômicas e o enfoque da política externa estabelecidas no governo

\footnotetext{
${ }^{2}$ Foram pesquisados os jornais Folha de São Paulo, Estado de são Paulo e Valor Econômico Online do período 2003- 2010, a Revista Brasileira de Comércio Exterior e a revista eletrônica Ponto de Vista, disponível no site do Núcleo de Estudos do Empresariado, Instituições e Capitalismo (NEIC).
} 
Lula; enfim, no capítulo quatro, organizo os dados do material empírico coletado de diversas fontes (documentos, publicações, notícias de jornal e revistas) e mapeio o posicionamento do setor empresarial acerca das negociações da OMC, Mercosul e Mercosul- União Européia. 


\section{CAPÍTULO 1 EVOLUÇÃO DA REPRESENTAÇÃO EMPRESARIAL NO BRASIL}

O histórico da representação empresarial no Brasil pode ser apresentado em quatro fases distintas. Esta periodização visa facilitar a compreensão das etapas do ativismo da classe empresarial. A primeira fase tem início em meados de 1930 com o surgimento das entidades oficiais de representação da classe empresarial e vai até o início dos anos 1990. Nessa fase, predominou certa convergência entre o empresariado e o governo, com pouco posicionamento autônomo dessa classe e grande intervencionismo estatal. A seguir, o período que vai do início do Governo Collor até a eleição de Fernando Henrique Cardoso (1990-1994) é uma fase de transição da organização do setor empresarial, impulsionada pelo advento da abertura econômica do país e do início das negociações do Mercosul.

A terceira fase abrange o período dos dois governos Cardoso até o início do Governo Lula (1994-2003) e marca oito anos de negociação da ALCA (Área de Livre Comércio das Américas). É a partir de negociações multilaterais como o Mercosul e sobretudo a ALCA, que a classe empresarial fica atenta à idéia de que tais acordos tinham impacto para seu setor e, por isso, ela não deveria ficar alheia a esses processos de negociações. Finalmente, o último período abrange os dois governos do presidente Lula (2003-2010), no qual, apesar da ampliação do diálogo entre o governo e a classe empresarial, este setor parece ter reduzido o nível de interesse nas negociações internacionais. Reafirmo que o principal objetivo desse trabalho é detectar como o empresariado reagiu às mudanças na política externa desse último período.

Veremos, a seguir, no primeiro capítulo, que a maior parte da literatura do tema indicou a ausência de ação organizada conjunta da classe empresarial, enquanto uma literatura mais recente detectou uma mudança no padrão de representação do setor na década de noventa. Este capítulo está dividido em duas sessões principais: a primeira remonta brevemente o histórico da representação da classe empresarial no país e suas principais fases; a segunda, aborda os dois principais argumentos da literatura do tema. Um dos argumentos classifica o setor como incapaz de organizar-se coletivamente através de uma entidade de cúpula, incapaz de coordenar interesses, de formular uma agenda autônoma em relação à agenda do governo e, por fim, como um setor ausente da formulação de políticas, especialmente da política externa; de outro lado, há a literatura que 
observa o surgimento de um novo padrão de representação de interesses do setor empresarial na década de 1990, a partir de movimentos como custo Brasil e as negociações da ALCA.

\subsection{OS PADRÕES CORPORATIVO E EXTRA-CORPORATIVO DE REPRESENTAÇÃO}

O início da primeira fase da representação empresarial no Brasil se dá com a emergência da industrialização, na década de 1930, que marca o início do corporativismo empresarial getulista controlado pelo Estado. O contexto era de formação de um Estado centralizado, com amplos poderes de intervenção nas esferas econômica e social, bem como capacidade de controle sobre os grupos sociais emergentes por meio da montagem do sistema corporativo. Esse aparelho apresentava como estrutura básica: um sistema de contribuição compulsória; a centralização da tomada de decisão no governo - excluindo a estrutura político partidária desse processo; e uma estrutura de representação vertical, atribuída ao modelo confederativo (OLIVEIRA, 2003).

A estrutura corporativa de representação empresarial tutelada pelo Estado é composta pelos sindicatos locais, segundo ramo de atividade industrial, pelas federações representando as indústrias regionais - circunscritas aos estados - e pela Confederação Nacional da Indústria, organização de cúpula que representa o conjunto da indústria nacional. A CNI surge tendo como pilares o princípio da unicidade sindical, a obrigatoriedade da contribuição financeira e a garantia do monopólio da representação.

A estrutura extra-corporativa, por sua vez, é formada pelas associações civis voluntárias, setoriais e de abrangência nacional. Organizadas de forma autônoma, tinham afiliação e contribuição de caráter voluntário. Apesar de seu surgimento datar do início do processo de industrialização, só se expandiram no surto desenvolvimentista dos anos $50 \mathrm{e}$ no período do Milagre Econômico dos governos militares (DINIZ, 2002).

Vê-se que o empresariado conta com uma estrutura de representação complexa e diversificada que abarcava múltiplos canais de participação, porém, ausente de uma instância aglutinadora de interesses supra-setoriais. Embora tenha havido a criação da Confederação Nacional da Indústria, da Confederação Nacional da Agricultura (CNA) e da 
Confederação Nacional do Comércio (CNC) pelo governo, a fase do corporativismo varguista caracteriza-se pela ausência de uma classe empresarial coesa (BIANCHI, 2001) e de uma entidade de cúpula com representatividade expressiva.

A partir da década de 1950, o setor industrial torna-se mais dinâmico e passa a haver um projeto para que ele seja a base da economia nacional. Essa fase conta com a projeção nacional de uma das principais entidades de classe do setor industrial, a Federação da Indústria do Estado de São Paulo (FIESP) e o amadurecimento de um projeto industrializante do empresariado que integrou a matriz ideológica do governo Juscelino Kubitscheck. Porém, à despeito do crescimento da industrialização, da existência do Congresso Nacional e de uma estrutura partidária, a relação do empresariado com o Estado continuou a ser conduzida pelo Executivo (BIANCHI, 2001). Nessa conjuntura, as associações setoriais paralelas tinham mais sucesso na articulação das demandas econômicas corporativas dos distintos ramos de atividade com o governo federal e, ao lado do sistema de representação corporativa, formavam um sistema híbrido de representação do interesse do empresariado.

A seguir, o golpe militar de 1964 contou com o apoio do empresariado, que passou a ocupar importantes cargos no governo, tendo maior atuação política durante a ditadura. Entretanto, essa participação política era localizada, pois o Estado, nesta fase, continuou a ser o principal condutor do processo de industrialização. O período militar pode ser subdividido em três fases em relação à atuação da classe empresarial. Entre 1964 e 1967, houve forte repressão política e execução de políticas ortodoxas de estabilização econômica, com resultados recessivos sobre as atividades industriais. Posteriormente, durante o Milagre Econômico, ocorreu considerável aumento da capacidade organizacional do empresariado industrial e continuidade do sistema dual de representação - corporativa e associativismo setorial. Houve aumento do número de associações paralelas e expansão dos setores industriais de ponta, que geraram ampliação da presença dos interesses industriais no Estado e a criação de arenas de negociação entre o setor público e o privado.

Num terceiro momento, a partir do governo Geisel, os empresários voltaram a sofrer maior afastamento das esferas definidoras da política econômica. O intervencionismo estatal intenso, os investimentos econômicos e o protecionismo conferidos aos setores 
vistos como estratégicos, somados à interlocução individualizada ou por meio de associações setoriais, levaram a uma atuação defensiva do empresariado.

No plano da política externa, o foco em demandas protecionistas por parte do empresariado também repercutiu no baixo engajamento desse segmento nos processos de negociações internacionais, já que o setor buscava proteger o mercado nacional (OLIVEIRA, 2003) ${ }^{3}$.

Nos anos 70, com o Milagre Econômico em vigor e o aprofundamento do modelo de substituições por importações, a industrialização chega a níveis inéditos e o empresariado continuava com pouco acesso aos canais institucionais do governo e sob forte intervencionismo Estatal. Assim, foi um período de consolidação das organizações paralelas frente à estrutura corporativa tradicional e conseqüente fracionamento da representação empresarial. A quebra do monopólio da representação corporativa tradicional, que passa a ter um papel cada vez mais complementar, dá lugar à centralidade crescente das associações setoriais nacionais dotadas de maior autonomia em face da legislação sindical corporativa. Isso resultou na especialização e setorização da representação dos interesses do setor empresarial e alargamento da estrutura extracorporativa, o que conferiu maior complexidade à estrutura dual de representação do empresariado (DINIZ, 2002).

Em meados de 1974, no contexto de crise econômica provocada pelo "choque do petróleo", os empresários protestaram contra a estatização e excesso de intervencionismo estatal (poder da tecnocracia). Isso significava o início de um novo modo de pensar, porém sem rompimento dos vínculos - não se tratava de uma oposição direta, pois o empresariado queria mais participação e não um rompimento com o regime militar (BIANCHI,2001).

A crise econômica da década de 1980 - marcada pelo colapso do modelo nacionaldesenvolvimentista e de substituições de importações e por períodos recessivos, com altas taxas de inflação -, reduziu ainda mais a capacidade de organização do empresariado.

Além disso, o surgimento de entidades empresariais que rompiam com a estrutura do padrão corporativo empresarial contribuiu para manter sua composição fragmentada e

\footnotetext{
3 Amâncio de Oliveira afirma que um indicador do baixo engajamento do empresariado nas negociações internacionais e sua ação voltada para o protecionismo e para o plano doméstico é sua participação defensiva nas negociações da ALALC (início da década de 1960), nas rodadas de negociações do GATT nas décadas de 1960 - 80 e nas negociações da Área Latino-Americana de Integração (Aladi), na década de 1980.
} 
complexa na década de 1980. Um exemplo são as entidades criadas nesse período - o Instituto Liberal, o Instituto de Estudos para o Desenvolvimento Industrial (IEDI) e o Pensamento Nacional das Bases Empresariais (PNBE), que consistiam em uma alternativa ao modelo tradicional de representação patronal (BIANCHI, 2001) ${ }^{4}$.

Diniz (2004) considera o surgimento dessas chamadas novas organizações empresariais como uma tentativa dos empresários de preencher uma brecha no campo da produção de idéias e da difusão de princípios ideológicos relacionados com o desenvolvimento do capitalismo brasileiro (o IEDI, a exemplo, fazia estudos direcionados à formulação de uma política industrial para nortear o processo de inserção do país no mercado internacional, porém preservando o espaço da produção interna).

Os estudos a respeito do empresariado no Brasil (BIANCHI, 2001; DINIZ, 2002) apontam que teria ocorrido um esgotamento dessas organizações durante o primeiro governo Fernando Henrique Cardoso - 1994 a 1998 - pois o foco desse governo, no período, estava nas reformas liberalizantes e não essencialmente na política industrial, provocando uma inflexão nas trajetórias desses institutos.

Vale destacar que até os anos 80, à despeito da centralidade decisória Estatal e de momentos, ora de ampliação, ora de redução do acesso do empresariado aos processos decisórios, o balanço desse período mostra que, a grosso modo, vigorou um pacto entre empresariado e Estado, no qual o setor empresarial tinha algum acesso à burocracia estatal (por vezes através canais informais) e o Estado fazia a manutenção de privilégios concedidos ao setor. O modelo econômico protecionista tutelado pelo Estado, voltado ao plano doméstico contribuiu para a ausência da concepção de uma agenda autônoma do empresariado, sobretudo referente à política exterior.

Enquanto vigorava o modelo de substituição de importações, o tratamento das demandas institucionais, corporativas e de articulação política ficava por conta da representação patronal (conexão com o Estado), e no universo micro, as associações

\footnotetext{
${ }^{4}$ O IEDI (1989) propõe, a partir da crise do modelo de substituição de importações, criar novas estratégias de desenvolvimento, porém, segundo Álvaro Bianqui, o instituto queria apenas elaborar uma política empresarial e não representar o empresariado. O PNBE, por sua vez, constatava a necessidade de organizar o empresariado e, além disso, detectava a ausência de uma plataforma empresarial que lidasse com as questões abordadas na Constituinte e a fraca capacidade das entidades corporativas de representação do empresariado.
} 
setoriais ${ }^{5}$ ajudavam o empresariado a resolver pontualmente seus conflitos e interesses produtivos. Cabe destacar que a partir de meados dos anos 80 , observou-se um expressivo deslocamento da ação dos interesses organizados do Executivo para o Legislativo, mediante a difusão da prática do lobby, valorizando-se o Legislativo como espaço de pressão dos grupos empresariais.

No final da década de 1980, as idéias do consenso de Washington foram tomadas pelo empresariado nacional como o caminho para o progresso, em substituição ao modelo nacional-desenvolvimentista, que significava, então, o retrocesso. No novo contexto, o Estado não era mais visto como capaz de ser o condutor do desenvolvimento, nem o articulador político dos interesses empresariais e no aspecto micro, não havia mais segurança de que de os interesses pontuais do setor seriam conservados. A entrada de produtos estrangeiros impulsiona a competição interna e o empresariado, então, se encontra sob impacto da abertura. É nesse momento, com o início do Governo Collor, que começa a segunda fase do ativismo da classe empresarial, tratando-se de uma fase de transição.

As mudanças econômicas inauguradas pelo Governo Collor (1990-1992) - abertura da economia ao capital internacional, desregulamentação financeira, privatização de empresas públicas, ingresso de novas elites empresariais estrangeiras no país, abandono de políticas industriais e de grandes subsídios ao empresariado - dificultavam a sustentação do posicionamento protecionista do setor e acabou por desmontar as bases de representação empresarial e capacidade de organização que já era reduzida. (OLIVEIRA, 2003; DINIZ, 2002).

Observa-se que empresários de diversos setores convergiam para adoção do novo modelo econômico, contudo houve desacordo em relação à forma e ritmo de implementação de algumas medidas da nova agenda como a privatização e a abertura comercial. Alguns setores ainda defendiam certo grau de protecionismo e a prática de subsídios (BRESSER-PEREIRA \& DINIZ, 2009; DINIZ, 2002) - ou seja, tinham uma orientação estratégica focada no plano doméstico e não internacional.

\footnotetext{
5 Atualmente, as associações paralelas englobam empresas dos setores tradicionais e modernos como a exemplo: a ABIA (indústria e alimentos), a ABIFA (indústria e fundição), a ANFAVEA (indústria de veículos automotores), a ABBINEE (indústria eletroeletrônica) e a ABDIB (infra-estrutura e indústrias de base).
} 
Não houve alteração nos padrões de representação empresarial para maior articulação da internacionalização econômica (OLIVEIRA, 2003). Houve, desse modo, baixa intervenção do empresariado na definição da política externa brasileira no início do governo Collor, postura que permaneceu no início das negociações do Mercado Comum do $\mathrm{Sul}^{6}$. Somente numa fase mais avançada do processo de negociação do Mercosul (1992/1993), os órgãos centrais de representação do empresariado (CNI, Associação Brasileira de Comércio Exterior - AEB - e CNA) começaram a dialogar com o governo, porém muita coisa já havia sido negociada sem a participação do setor privado.

Oliveira (2003) destaca as razões que levaram ao baixo nível de engajamento do setor privado nas negociações do Mercosul e do empresariado, em geral, nas negociações internacionais: um viés governamental do projeto do Mercosul, ausência de risco no processo pela correlação de forças entre os países envolvidos ser favorável ao Brasil, o fato de o projeto fazer parte de uma política de liberalização econômica (ainda que o empresariado reivindicasse mecanismos de proteção setorial, apoiava essa liberalização) e certo ceticismo, por parte do setor privado, de que o Mercosul realmente se efetivaria.

A terceira fase da representação empresarial compreende o período dos dois governos Fernando Henrique Cardoso. No período de 1994 a 1998, houve intensa reestruturação do parque industrial brasileiro: fechamento de empresas, falências, fusões entre empresas nacionais e com empresas estrangeiras, queda do nível de emprego na indústria e desindustrialização - foram os efeitos da abertura econômica realizada desde o período Collor. Os setores mais prejudicados foram as indústrias têxtil, de máquinas e equipamentos, autopeças e produtos eletrônicos. (BRESSER-PEREIRA \& DINIZ, 2009; DINIZ, 2002).

Em resposta a esse cenário, o empresariado nacional não teve uma reação uniforme. Um grupo de empresários industriais ligados ao IEDI manteve oposição a total abertura comercial. Os demais, e aí, destaca-se a FIESP e a CNI, defendiam as reformas orientadas para o mercado. Os setores empresariais adotaram um conjunto de ajustes para ganhar competitividade e reduzir custos produtivos. Oliveira (2003) destaca que ao final da década de 1990, os setores que tiveram êxito em sua reestruturação - a exemplo, os setores da

\footnotetext{
${ }^{6}$ Amâncio de Oliveira (2003), relata detalhadamente através de entrevistas a membros do governo e a entidades de representação empresarial do Brasil encarregados de acompanhar as negociações do Mercosul, o papel coadjuvante dos setores empresariais nas definições referentes ao processo de integração.
} 
indústria têxtil e calçadista - passaram a fazer demandas junto ao governo para a conquista de novos mercados internacionais.

Nesse terceiro momento, há uma inflexão na literatura em relação ao diagnóstico da representação empresarial, que veremos a seguir. Autores como Mancuso e Oliveira apontam que foi uma fase de grande ativismo e ação coletiva organizada da classe empresarial.

\subsection{VISÕES DA LITERATURA SOBRE O COMPORTAMENTO EMPRESARIAL}

Diniz (2002) remonta o diagnóstico que predominou até então na história da representação empresarial: a inexistência de uma entidade superior com capacidade de organizar e articular os interesses do setor empresarial, que atribuiu a esse setor uma fragilidade enquanto ator coletivo. Grande parte dos estudos sobre o empresariado brasileiro caracterizam o setor como incapaz de agir coletivamente nos âmbitos intrasetorial e inter-setorial. Essa incapacidade de ação conjunta é caracterizada como conseqüência direta do sistema de representação corporativista.

De fato, os estudos do percurso do setor empresarial no processo de industrialização brasileira atribuem a baixa capacidade de ação coletiva do setor à herança da estrutura corporativa inaugurada na década de 1930, à inexistência de uma entidade multissetorial de representação da classe ${ }^{7}$ e à incapacidade de interlocução com demandas de outros setores.

O debate em torno da força política do empresariado na década de 1990 com a abertura comercial e as reformas orientadas para o mercado, segue duas direções distintas. Parte dos autores (Diniz, Boschi, Bresser-Pereira) reafirma que nessa década, permanece a escassa participação política do empresariado nacional e, ainda, que essa participação perdeu força e influência no período. A inexistência de ação coletiva significativa e a postura predominantemente protecionista teriam sido demonstradas no modo de atuação do empresariado nas negociações internacionais.

\footnotetext{
${ }^{7}$ O sistema corporativista de representação do empresariado reúne entidades setoriais de grau superior, cujos líderes não são representativos, pois sua legislação atribui mesmo peso tanto às associações com baixa importância econômica quanto as mais importantes, causando uma distorção de representação da classe na escolha das lideranças.
} 
Para os autores que defendem o argumento da fraqueza política do empresariado nacional na década de 1990, o setor industrial perdeu papel político na definição da estratégia nacional de desenvolvimento. Argumentam que, sob diretrizes da nova ordem econômica, a lógica centralizadora das grandes corporações internacionais teria comandado a inserção-integração das economias nacionais numa concentração de poder de escopo transnacional, processo marcado por graves assimetrias políticas e econômicas. (BRESSER-PEREIRA \& DINIZ, 2009).

Diniz (2002) ressalta a importância dos procedimentos político-institucionais do processo de formulação e implementação de políticas nesse período. Observa que a concentração do poder decisório no Executivo - na alta tecnocracia governamental - e o padrão desigual da relação de poderes (a subordinação do Legislativo perante o Executivo, através, dentre outros mecanismos, de decretos-leis e Medidas Provisórias), contribuíram para o aprofundamento da tendência tradicional do empresariado da utilização de vínculos pessoais e informais como acesso às instâncias governamentais.

Enfim, para os autores que defendem que o empresariado é um ator político fraco, o período pós-reformas (fim da década de 1990), apresenta uma estrutura de representação do empresariado ainda mais fragmentada e especializada. Segundo essa tese, a deficiência na ação coletiva é a principal causa da fraqueza política do empresariado, o que dificultou que esse setor exercesse um papel de liderança na lacuna formada entre a queda do antigo modelo de desenvolvimento (nacional-desenvolvimentismo) e o novo modelo que surgiu nos anos 90. Logo, a literatura tradicional analisa o setor empresarial como um ator político fraco em toda a década de 1990.

De lado oposto, outra parte da literatura (Oliveira, Mancuso) aponta para uma atuação inédita e protagonista do setor empresarial na política nacional e nas negociações internacionais nesse período. Afirmam que com a abertura econômica e, sobretudo, com as negociações da Área de Livre Comércio das Américas (ALCA), o setor empresarial não apresentou uma postura de debilidade política e falta de organização coletiva.

Conforme Mancuso:

no plano doméstico o desafio da concorrência elevou a competitividade ao patamar de objetivo prioritário a ser perseguido pelas empresas. Por causa disso, a redução do Custo Brasil tornou-se a bandeira sob a qual o empresariado se reuniu. Custo Brasil é uma expressão que sintetiza o conjunto de fatores que prejudicam a competitividade das empresas do 
país diante de empresas situadas em outros países. Já no plano externo, o empresariado criou a Coalizão Empresarial Brasileira (CEB), entidade multissetorial formada para participar de processos de negociação internacional em curso - como é o caso da ALCA. (MANCUSO, 2006, p.150).

A idéia de reduzir o custo Brasil (fatores que prejudicam a competitividade da empresas do país) ${ }^{8}$ surgiu do seminário “custo Brasil - Diálogo com o Congresso Nacional", realizado em 1995 no âmbito da CNI, com a participação de industriais de todo o Brasil, deputados federais e senadores. Os industriais adotaram uma agenda legislativa comum, formada por temas que superaram as diferenças setoriais. Conforme Mancuso (2004) este exemplo de superação dos problemas de ação coletiva de um setor heterogêneo como o empresarial se deu por dois fatores: o primeiro foi impacto da abertura econômica da década de 1990, que ao aumentar o grau de concorrência fez com que as empresas decidissem elevar seu patamar de competitividade; e o segundo foi o fato das organizações industriais decidirem realizar um trabalho coletivo permanente de monitoramento das proposições legislativas que tinham algum tipo de impacto sobre o custo Brasil.

No caso da criação da CEB, Amâncio de Oliveira (2003) diagnosticou o protagonismo do empresariado na organização da ação coletiva. Durante as primeiras negociações da ALCA como o Fórum Empresarial das Américas, em Denver (1995) e a Reunião Ministerial de Cartagena (1996), os empresários brasileiros constataram que possuíam um baixo grau de engajamento e integração se comparados aos norte-americanos. Perceberam, também, que a ALCA traria grandes riscos e uma nova onda de abertura comercial, e, assim, era necessário preparar-se para uma negociação de tamanha complexidade.

A realização do Fórum Empresarial seguinte ocorreu no Brasil, e, conforme afirma Oliveira:

Ficou combinado, entre empresários e governo, que a organização da reunião ministerial ficaria a cargo do Itamaraty; a parte logística, a cargo de organizações empresariais e governamentais locais, e a parte substantiva do Fórum Empresarial, a cargo da Confederação Nacional da Indústria (OLIVEIRA, 2003, p.26).

\footnotetext{
${ }^{8}$ Os fatores que compõem o custo Brasil são: excesso e má qualidade da regulação da atividade econômica, legislação trabalhista inadequada, sistema tributário que onera a produção, elevado custo de financiamento da atividade produtiva, infra-estrutura material insuficiente e infra-estrutura social deficiente.
} 
Assim, a CNI ficou encarregada de organizar e preparar o setor privado para as negociações. Para isso, ela estabeleceu contato com organizações empresariais do Brasil e de outros países. Essa articulação e processo de organização do empresariado para o Fórum Empresarial culminou na formação da Coalizão Empresarial Brasileira. Coube à CEB, então, processar as diversas demandas dos setores produtivos, harmonizá-las e apresentá-las ao governo de forma unificada em nome de todo o empresariado nacional.

A criação da CEB é, então, considerada por Oliveira (2003) como um avanço na história da representação do empresariado por se tratar de uma entidade de cúpula multissetorial com abrangência nacional e também por seu foco de atuação estar voltado para um processo de negociação internacional. A CEB passou a coordenar as demandas diversificadas do setor privado, de empresários e empresas isoladas, de associações de classe, federações e confederações, para tentar influenciar a dinâmica de internacionalização. Oliveira também destaca a inovação no esforço de convergência entre o governo e o setor privado neste caso: o governo incorporou as demandas do empresariado e a CEB buscou amenizar posições liberalizantes do setor empresarial muito dissonantes das do governo.

A inovação se dá no momento em que o empresariado, de forma independente, passou a ter agenda e posicionamento. Oliveira destaca três pontos importantes na CEB enquanto entidade de cúpula: representação de distintos interesses empresariais, formulação de políticas do setor privado e influência junto ao governo ${ }^{9}$. A CEB passou a funcionar como um fórum de participação e articulação de setores econômicos distintos (indústria, comércio e serviços). Sua estrutura passou a ser adotada no acompanhamento de negociações de outras arenas internacionais: Mercosul, Mercosul-União Européia e OMC.

$\mathrm{Na}$ avaliação de Oliveira (2003), a CEB representou melhor os interesses da indústria e da agricultura nas negociações da ALCA. De maneira geral, a posição da CEB coincidiu com a posição governamental nessa negociação. Em alguns momentos ela teve posição autônoma em relação ao governo, pois era mais assertiva em novos temas como investimentos, serviços e compras governamentais. O setor industrial, sobretudo, o mais

\footnotetext{
${ }^{9}$ Oliveira (2003) relata que a CEB fazia sondagens setoriais sobre temas de relevo em termos de inserção internacional. A Coalizão recebia também position papers de todos os níveis do universo empresarial que serviam de subsídio aos cronogramas dos fóruns empresariais e eram entregues ao governo para subsidiar a posição governamental nos encontros oficiais. A CEB também fez reuniões periódicas com empresários e técnicos representantes de entidades de classe empresarial.
} 
conservador (papel e celulose, químico, eletroeletrônico, bens de capital), sobressaiu na Coalizão enquanto os setores mais favoráveis à abertura e uma integração competitiva (poucos setores da indústria, serviço e comércio), tiveram menos peso. Um dos motivos disso é que a indústria, devido ao antigo modelo de substituição de importações, tinha canais mais estreitos de diálogo com o governo do que os demais setores. O Itamaraty e a indústria protecionista fizeram juntos, o posicionamento anti-ALCA nas negociações.

Apesar dos interesses não terem sido representados pela CEB igualmente e sua atuação não tenha sido totalmente satisfatória para o conjunto do setor produtivo (os setores de serviços e comércio que eram favoráveis à ALCA tiveram pouca influência nas negociações; o setor agrícola, que queria a eliminação das barreiras agrícolas dos EUA, não alcançou esse objetivo; e a representação de diferentes níveis empresariais levou a um posicionamento genérico demais e criou uma Coalizão de caráter defensivo), o saldo é positivo pelo caráter inovador da entidade.

Assim, o surgimento da CEB e o movimento pela redução do Custo Brasil, nessa linha de argumentação, mostram o empresariado como um ator político forte na década de 1990, sobretudo frente às negociações internacionais, contraponto a tese da debilidade política tradicional do setor. (MANCUSO 2007; OLIVEIRA, 2003).

$\mathrm{Na}$ análise da quarta fase da representação empresarial (2003-2010), que compreende os dois governos Lula, verificaremos se a atuação da classe empresarial na formação da CEB e no movimento pela redução do Custo Brasil foram somente atuações pontuais do empresariado nos anos 90 ou se essa postura ativa permaneceu na década subseqüente. Para subsidiar o estudo da atuação empresarial frente às questões internacionais desse último momento, farei um breve diagnóstico do papel da Confederação Nacional da Indústria para a classe empresarial, já que a entidade, através da CEB, torna-se um canal de articulação de demandas do setor junto ao governo nas negociações internacionais. Destacaremos, na seção seguinte, a contribuição da CNI na atuação do empresariado nas negociações internacionais. 


\section{CAPÍTULO 2 CONTRIBUIÇÕES DA CNI PARA A CLASSE EMPRESARIAL}

A CNI surgiu em 1938, a partir da criação da Confederação Industrial do Brasil datada de 1933, tendo sido uma iniciativa de quatro federações da indústria: São Paulo, Minas Gerais, Rio de Janeiro e Rio Grande do Sul. Inicialmente atuou para superar os problemas gerados pela Segunda Guerra Mundial, realizando estudos sobre o planejamento das atividades produtivas do Brasil e reequipamento do parque manufatureiro. Na década de 1940, com o objetivo de incentivar a formação de mão-de-obra industrial, a CNI estruturou a criação do Serviço Nacional de Aprendizagem Industrial (SENAI), em 1942, e do Serviço Social da Indústria (SESI), em 1946.

No período de 1940-80, concentrou-se na formação e diversificação do parque industrial brasileiro; a partir do final da década de 1980, passou a atuar na competitividade do produto brasileiro, inserção das empresas brasileiras no mercado internacional,

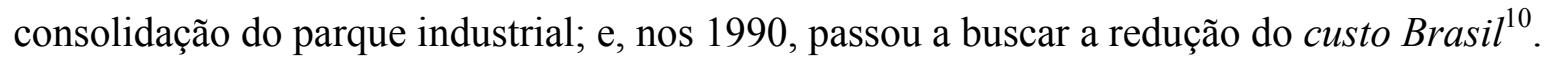

De fato, no início dos anos 90, o segmento industrial avaliava ter uma estrutura produtiva consolidada, porém, considerando os padrões de produtividade e concorrência alterados pelo processo de globalização, a entidade confederativa passou a defender como objetivo principal do setor a melhoria dos índices de competitividade da indústria nacional e sua integração à economia mundial. Assim, a CNI tem grande importância no auxílio às empresas no processo de abertura comercial e no aperfeiçoamento tecnológico da indústria. Outra função importante da entidade nas últimas décadas foi fortalecer a ação articulada das entidades que compõem o Sistema da Indústria - SENAI, SESI e o Instituto Euvaldo Lodi (IEL) ${ }^{11}$.

Nos dias atuais, a CNI é a principal associação do sistema corporativista de representação do empresariado industrial. Por ser uma associação de cúpula, pode se dedicar à promoção dos interesses coletivos desse segmento, com o objetivo de defender e

\footnotetext{
${ }^{10}$ Informações obtidas no site da CNI:<http://www.cni.org/portal/data/pages $>$. Acesso em 03 dez. 2010.

${ }^{11}$ O SENAI é o maior complexo de educação profissional da América Latina, centrado na qualificação de trabalhadores, prestação de serviços de pesquisa e informação tecnológica ao setor produtivo; o SESI tem trabalho focado na gestão de políticas de responsabilidade social e possui programas de educação, promoção da saúde, segurança no trabalho, além de incentivar desenvolvimento cultural e de lazer e esporte; o IEL, elo entre a indústria e o meio acadêmico, tem por objetivo promover o crescimento do setor por meio da capacitação empresarial, aperfeiçoamento da gestão e suporte à inovação. Ver site da CNI: $<$ http://www.cni.org/portal/data/pages>. Acesso em 03 dez. 2010.
} 
representar a indústria - tanto no âmbito das políticas públicas como em relação às negociações internacionais - para o acesso a um ambiente favorável aos negócios. A entidade busca garantir a participação da comunidade industrial na formulação de políticas públicas que beneficiem o ambiente de negócios.

Os recursos financeiros da CNI provêm do imposto sindical compulsório que as empresas legalmente estabelecidas pagam $(5 \% \text { do imposto destinam-se à CNI })^{12}$. Fazem parte da Confederação 27 Federações de Indústrias dos Estados e do distrito Federal, 1250 sindicatos patronais associados e 350 mil empresas de todas as unidades federativas do país.

Sediada em Brasília, a estrutura da entidade é composta por: diretoria, cuja função principal é administrar a confederação, integrada por seu presidente, o $1^{\circ}, 2^{\circ}$ e $3^{\circ}$ vicepresidentes, $1^{\circ}, 2^{\circ}$ e $3^{\circ}$ diretores financeiros, $1^{\circ}, 2^{\circ}$ e $3^{\circ}$ diretores secretários e 15 diretores substitutos; Conselho de Representantes, formado por dois membros de cada uma das 27 federações das indústrias - dos estados e do Distrito Federal - que compõem o órgão máximo da entidade, encarregado de traçar a política geral e as estratégias da CNI e no qual cada federação tem autonomia para nomear seus representantes; Conselhos Temáticos órgão consultivo composto por 11 Conselhos (compostos por líderes empresariais e representantes de federações e associações setoriais da indústria); Diretoria Executiva; Superintendência Corporativa e Superintendência de Serviços Compartilhados.

O Presidente da CNI acumula as funções de Presidente do Conselho Nacional do SENAI, do Conselho Superior do IEL e de Diretor do Departamento Nacional do SESI e a diretoria da entidade é renovada a cada quatro anos, sendo que o presidente só pode ser reeleito uma vez, para mandato subseqüente.

A Diretoria da CNI apresenta as seguintes unidades: Diretoria Executiva; Diretoria de Relações Institucionais; Diretoria de Operações; Unidade de Gestão de Defesa de Interesses; Unidade de Pesquisa, Avaliação e Desenvolvimento; Unidade de Relações do Trabalho e Desenvolvimento Associativo; Unidade de Política Econômica; Unidade de

\footnotetext{
${ }^{12}$ Do montante arrecadado com a contribuição sindical, $60 \%$ ficam com o sindicato que representa a categoria - mesmo se a empresa não for sindicalizada -, enquanto o Ministério do Trabalho recebe $20 \%$ e a federação estadual da indústria do estado em questão, $15 \%$. À CNI cabem 5\% do total. Na ausência do sindicato, porém, a federação fica com $60 \%$, o Ministério do Trabalho com $20 \%$ e a CNI com $20 \%$. Ver site da CNI. Ibidem.
} 
Assuntos Legislativos; Unidade de Negociações Internacionais; Unidade de Meio Ambiente; e Unidade de Estudos e Políticas Industriais e Inovação.

Os Conselhos Temáticos são 11 atualmente. Eles se reúnem periodicamente para discutir e apresentar informações e propostas que orientam as decisões da diretoria e as ações da CNI na defesa dos interesses da indústria brasileira. São eles:

TABELA 1

Conselhos Temáticos da CNI

\begin{tabular}{|c|c|}
\hline Assuntos Legislativos (CAL): & $\begin{array}{l}\text { Analisa e orienta a ação política da CNI junto ao } \\
\text { Congresso Nacional, com foco no } \\
\text { acompanhamento e na busca de influência no } \\
\text { processo legislativo. Articula apoio político a } \\
\text { projetos de interesse do setor industrial, divulga } \\
\text { posições da CNI junto ao Congresso Nacional e } \\
\text { participa do processo de formulação da Agenda } \\
\text { Legislativa. }\end{array}$ \\
\hline Educação (COED) & $\begin{array}{l}\text { Promove o debate sobre a educação brasileira, } \\
\text { nos vários níveis e modalidades, a partir da visão } \\
\text { da indústria e com o objetivo de promover uma } \\
\text { capacitação profissional para os jovens. } \\
\text { O Conselho também identifica e apóia a difusão } \\
\text { de práticas educacionais. }\end{array}$ \\
\hline Infraestrutura (COINFRA) & $\begin{array}{l}\text { Avalia, acompanha e propõe sugestões sobre a } \\
\text { disponibilidade e qualidade da infraestrutura no } \\
\text { Brasil, principalmente nas áreas de energia, } \\
\text { transportes, portos, saneamento básico e } \\
\text { telecomunicações. Também acompanha e } \\
\text { influencia o desenvolvimento dos marcos } \\
\text { regulatórios destes setores. }\end{array}$ \\
\hline Integração Internacional (COINTER) & $\begin{array}{l}\text { Analisa a política de comércio exterior brasileira } \\
\text { e de negociações internacionais e orienta o } \\
\text { relacionamento da CNI com órgãos } \\
\text { governamentais responsáveis por sua } \\
\text { implementação. Exerce influência na legislação } \\
\text { de comércio exterior e na busca pela integração } \\
\text { da indústria brasileira com o mercado mundial. } \\
\text { Para tal, realiza ações de promoção comercial, de } \\
\text { investimentos e de acordos comerciais bilaterais } \\
\text { e multilaterais e de integração econômica. }\end{array}$ \\
\hline Integração Nacional (CIN) & $\begin{array}{l}\text { Estuda as diferenças regionais, com o objetivo de } \\
\text { propor alternativas para que o desenvolvimento } \\
\text { do país se dê de forma equilibrada, tanto nas suas }\end{array}$ \\
\hline
\end{tabular}




\begin{tabular}{|c|c|}
\hline & $\begin{array}{l}\text { dimensões econômicas, políticas e } \\
\text { quanto na territorial. Contribui para o } \\
\text { alinhamento estratégico e formação do } \\
\text { posicionamento da CNI em relação a assuntos } \\
\text { relacionados à redução das disparidades } \\
\text { econômicas do país. }\end{array}$ \\
\hline Meio Ambiente (COEMA) & $\begin{array}{l}\text { Acompanha a legislação, desenvolve propostas } \\
\text { de políticas e estimula práticas voltadas para a } \\
\text { ecoeficiência. Promove o debate com } \\
\text { especialistas e autoridades na área ambiental e } \\
\text { avalia as políticas públicas de licenciamento } \\
\text { ambiental, controle e qualidade ambiental, } \\
\text { biodiversidade e florestas, tratamento e } \\
\text { disposição de resíduos, entre outras. Formula } \\
\text { linhas de ação para aumentar a competitividade } \\
\text { das indústrias e a preservação do meio ambiente. }\end{array}$ \\
\hline Micro e Pequena Empresa (COMPEM) & $\begin{array}{l}\text { Contribui para a elaboração e a aplicação de } \\
\text { políticas relativas ao tratamento diferenciado aos } \\
\text { pequenos negócios industriais, com vistas a sua } \\
\text { competitividade e desenvolvimento. Realiza } \\
\text { estudos e propõe estratégias para questões de } \\
\text { interesse das microempresas e empresas de } \\
\text { pequeno porte, como inovação tecnológica, } \\
\text { capacitação empresarial e acesso ao mercado } \\
\text { externo. }\end{array}$ \\
\hline Política Econômica (COPEC) & $\begin{array}{l}\text { Estuda as mudanças na política econômica, } \\
\text { formula propostas, acompanha a conjuntura do } \\
\text { país, avalia e propõe políticas nas áreas } \\
\text { monetária, creditícia, cambial, fiscal e tributária. } \\
\text { Também contribui para o alinhamento } \\
\text { estratégico e a formação do posicionamento da } \\
\text { CNI em relação a assuntos relacionados ao } \\
\text { crescimento econômico e ao desenvolvimento } \\
\text { nacional. }\end{array}$ \\
\hline $\begin{array}{c}\text { Política Industrial e Desenvolvimento } \\
\text { Tecnológico (COPIN) }\end{array}$ & $\begin{array}{l}\text { Elabora e acompanha a aplicação das políticas } \\
\text { que dizem respeito ao desenvolvimento } \\
\text { industrial e tecnológico, oferecendo subsídios } \\
\text { para o seu aperfeiçoamento. Promove debate } \\
\text { com especialistas e autoridades na área de } \\
\text { política industrial e de inovação e avalia as } \\
\text { políticas públicas para o setor. }\end{array}$ \\
\hline Responsabilidade Social (CORES) & $\begin{array}{l}\text { Apresenta propostas de alterações da legislação } \\
\text { sindical e trabalhista. Ainda atua examinando as } \\
\text { tendências do mercado de trabalho, políticas de } \\
\text { empregos e salários no país, além da legislação e } \\
\text { de relações internacionais do trabalho. }\end{array}$ \\
\hline
\end{tabular}




\begin{tabular}{|c|l|}
\hline $\begin{array}{c}\text { Relações do Trabalho e Desenvolvimento } \\
\text { Social (CRT) }\end{array}$ & $\begin{array}{l}\text { Estimula o desenvolvimento integrado e em rede } \\
\text { de ações e iniciativas de responsabilidade social } \\
\text { na federações, associações e empresas } \\
\text { industriais. Além disso, mapeia as diversas } \\
\text { formas de atuação das empresas nas questões } \\
\text { sociais, seus resultados e perspectivas de } \\
\text { sustentação e disseminação. }\end{array}$ \\
\hline
\end{tabular}

FONTE: CNI (2011)

As prioridades do setor industrial, o posicionamento a ser defendido e as estratégias e ações da CNI são definidos a partir da consulta às federações de indústrias, sindicatos, associações industriais e empresários. Para isso, a entidade realiza um processo permanente de consulta às bases organizando fóruns, conselhos empresariais e redes de relacionamento formadas por líderes empresariais.

A construção da agenda do setor se dá através das avaliações e propostas feitas por Conselhos Temáticos e Comissões Especiais, pelo Fórum Nacional da Indústria, pela Coalizão Empresarial Brasileira, pelo Encontro Nacional da Indústria, pelos Fóruns de Executivos da CNI, de Federações de Indústrias e de Associações setoriais e pela Mobilização Empresarial pela Inovação. ${ }^{13}$

Esse processo é complementado pela realização de estudos, pesquisas técnicas, levantamento de indicadores, seminários e oficinas que oferecem informações quantitativas e qualitativas que ajudam a identificar prioridades, revelar o desempenho da indústria e a buscar consensos em torno dos temas que têm impacto no setor industrial. ${ }^{14} \mathrm{~A}$ partir da divulgação de pesquisas, estudos e indicadores, a CNI busca fornecer subsídios para a tomada de decisão dos empresários. ${ }^{15}$

A Coalizão Empresarial Brasileira, por sua vez, reúne representantes de 122 organizações empresariais de diversos setores. ${ }^{16}$ Para organizar o posicionamento do setor

\footnotetext{
${ }^{13}$ A Mobilização Empresarial pela Inovação (MEI) é um movimento coordenado pela CNI que reúne líderes industriais, representantes de associações nacionais setoriais, de federações de indústrias e instituições públicas e privadas voltadas à inovação. O Comitê Empresarial da MEI é o órgão consultivo da CNI na área de inovação responsável pela avaliação, definição de posicionamentos e acompanhamento das ações do governo na área de inovação e desenvolvimento tecnológico.

${ }^{14}$ Para mais informações sobre a estrutura do processo de consulta da CNI ao setor industrial, consultar o anexo A deste trabalho.

${ }^{15}$ Confederação Nacional da Indústria. Mecanismos de consulta CNI. Confederação Nacional da Indústria : Brasília, 2009.

${ }^{16}$ Id. Ibidem.
} 
privado nas negociações de acordos comerciais com outros países ou blocos econômicos, a CEB possui um sistema de participação voluntária de empresas de qualquer setor econômico que busquem atuar no ramo dos negócios internacionais.

A CEB procura mediar o posicionamento do setor empresarial frente às negociações internacionais, mantendo, ao mesmo tempo, diálogo com os representantes do governo brasileiro. Atualmente, além de atuar nas negociações supracitadas (recomendações à agenda brasileira na Rodada Doha, da OMC; negociações entre o Mercosul e a União Européia; e atuação nas iniciativas relacionadas à agenda externa do Mercosul), a Coalizão também coopera com os trabalhos do Fórum Empresarial das Américas e da Seção Brasileira do Foro Empresarial Mercosul-União Européia.

Embora a Secretaria Executiva da CEB seja coordenada pela Confederação Nacional da Indústria, o Conselho de Orientação Estratégica (COE) - conselho composto por membros que representam as organizações empresariais de cúpula e entidades setoriais com relevante participação no comércio exterior brasileiro - atua separadamente. Além da CNI, fazem parte do quadro da CEB: a Confederação do Comércio, a Confederação das Instituições Financeiras (CNIF), a Confederação da Agricultura e da Pecuária, a Confederação dos Transportes (CNT), a Associação de Comércio Exterior do Brasil (AEB) e o Conselho de Empresários da América Latina (CEAL) (MATHIAS, 2011).

Em virtude do enfoque deste trabalho na análise da atuação da CNI no contexto de negociações internacionais, retomaremos, a seguir, os principais momentos em que a entidade representou o empresariado em processos de negociação dessa dimensão.

No processo de negociações da Aladi, na década de 1980, a CNI representou o setor privado na Comissão Nacional para assuntos da Aladi. Entretanto, na época, o posicionamento foi defensivo e pouco representativo, fruto da política industrial voltada à proteção do mercado doméstico.

Posteriormente, nas negociações do Mercosul, embora não tenha havido grande representação efetiva do empresariado como já mencionado, na fase mais avançada da negociação, a CNI, juntamente com a Associação Brasileira de Comércio Exterior e a CNA, se esforçaram para articular com o governo a posição dos interesses privados. 
Como já supracitado, Oliveira (2003) destaca na formação da Coalizão Empresarial Brasileira, o papel protagonista da CNI. A entidade não apenas articulou como também coordenou a representação de todo o setor privado nas negociações da ALCA.

O movimento do empresariado pela redução do custo Brasil, como citado, também resultou de um trabalho iniciado pela CNI e envolveu um conjunto grande de associações empresariais. Ao desenvolver um trabalho de acompanhamento das proposições legislativas que impactavam o custo Brasil, a entidade deu origem à Agenda Legislativa da Indústria, que é publicada anualmente desde 1996. Além de identificar quais projetos tem maior capacidade para reduzir a competitividade das empresas nacionais, a agenda apresenta uma síntese do posicionamento da indústria. Participam do documento diversas federações, confederações e organizações setoriais (OLIVEIRA \& MANCUSO, 2006). O papel importante da CNI, para Mancuso (2006), no caso do custo Brasil, foi o de arcar com os custos da ação coletiva para torná-la viável. ${ }^{17}$

Em síntese, se inicialmente, o foco da CNI estava na estruturação e diversificação do parque produtivo brasileiro, à medida que foram sendo intensificadas e ampliadas as relações comerciais internacionais do Brasil nos anos 1990, a CNI volta-se para a promoção da inserção do empresariado nas formulações de políticas comerciais, informando, capacitando o setor para as negociações e influenciando-as através do diálogo com o governo. Essa mudança de foco da CNI ocorreu porque a abertura comercial trouxe novos desafios e transformações ao setor. As mudanças na gestão da política externa ocorridas no Governo Lula, com a intensificação nas negociações internacionais e a projeção política do Brasil no cenário internacional também afetaram o posicionamento e modo de atuação da entidade, como veremos adiante.

\footnotetext{
${ }^{17}$ A teoria da ação coletiva (Olson, 1971) estuda os principais problemas ligados à provisão de um benefício coletivo. Um desses problemas é a existência dos caronas (atores que não se dispõem a colaborar com a obtenção de um benefício, contando que outros atores o façam por eles). Os caronas têm essa atitude para que outros arquem com os custos da ação coletiva enquanto eles aproveitam somente os benefícios. Tal atitude, por vezes, inviabiliza a própria obtenção do benefício ou a viabiliza em nível sub-ótimo. De acordo com Mancuso (2004), na agenda da redução do custo Brasil, a CNI, para resolver o problema da ação coletiva dessa natureza, desempenhou o papel de "empreendedor político", no sentido de ter decidido, por conta própria, assumir o ônus necessário à deflagração e organização da ação coletiva.
} 


\section{CAPÍTULO 3 GOVERNO LULA: MUDANÇAS DE ENFOQUE NA POLÍTICA EXTERNA}

A última fase da representação empresarial no Brasil analisada compreende os dois mandatos do governo Lula. O início do governo, em 2003, foi marcado por uma transição ordenada em que se mantiveram os compromissos internacionais. Conforme demonstram Diniz e Boshi (2007), a manutenção da estabilidade econômica, responsabilidade fiscal e respeito aos contratos assinados com os credores internacionais implicaram na manutenção de superávits primários. A política macroeconômica também permaneceu pouco alterada em relação ao governo anterior.

Destacaremos aqui dois pontos de mudança no novo governo: o enfoque da política externa e a proposta de implementação de uma política industrial afirmativa, com diálogo com o setor empresarial.

O final governo Fernando Henrique Cardoso (1994 -2002) coincidiu com certo recrudescimento das relações internacionais em face do início do governo de George W. Bush (2001) - o qual tinha ênfase no unilateralismo e voltava-se para questões de segurança (sobretudo após os atentados de 11 de setembro de 2001). Nesse período, o Brasil ampliou relações com países como China, Índia e África do Sul, enquanto tentava buscar maior diálogo com os Estados Unidos nas negociações da ALCA. Porém, poucos acordos foram efetivados em âmbito multilateral.

Veiga (2005) destaca que nos primeiros dois anos do governo Lula, nas negociações internacionais, prevaleceu uma continuidade com os eixos centrais da política econômica externa do Brasil herdada dos governos pós-abertura comercial no início dos anos 90: prioridade nas negociações multilaterais e uma aposta no sentido estratégico do Mercosul. De outro lado, o autor também denota uma mudança na hierarquia das agendas de negociação hemisférica e inter-blocos: o governo Lula prioriza a integração Mercosul- EU em detrimento da ALCA, ao contrário do governo FHC.

No entanto, apesar de manter alguns pontos da condução da política externa de seu predecessor, é certo que o governo Lula trouxe nova dimensão à diplomacia brasileira, intensificando a atuação internacional do país, sobretudo em relação à América do Sul, aos organismos internacionais e às potências emergentes do sul. Buscou elevar a posição de 
potência internacional do Brasil, tornar-se membro permanente do Conselho de Segurança da ONU e realizou alianças até então inéditas com a Rússia, a Índia e a China (Brics) e com a Índia e a África do Sul (Ibas).

No plano comercial, o governo Lula teve como desafio enfrentar quatro negociações econômicas internacionais distintas: negociações no Mercosul, negociação entre blocos com a União Européia e com os Estados Unidos na ALCA e negociações para fins de definição da agenda da Rodada Doha no plano multilateral (OMC) (VEIGA, Ibidem).

No caso da ALCA, o protecionismo comercial dos países desenvolvidos e as condições prejudiciais que recairiam sobre setores produtivos brasileiros caso as negociações fossem concluídas, inviabilizaram a concretização do acordo. As negociações da ALCA não conseguiram produzir um terreno de equilíbrio e entendimento entre as expectativas ambiciosas de Washington e concessões norte-americanas, especialmente em agricultura, que atendessem aos interesses do Brasil e do Mercosul.

Um dos motivos de o governo ter aprofundado a postura crítica em relação à ALCA, são as diretrizes em que o discurso do governo Lula estavam pautadas, ressaltadas por Veiga (Ibidem): crença na insuficiência da globalização para superação de problemas de desenvolvimento e pobreza, incentivo ao crescimento econômico direcionado também para o desenvolvimento social e enfoque num recorte Sul-Sul da diplomacia .

No âmbito da OMC, no governo Lula houve contribuição para o avanço das negociações multilaterais do Brasil, em que o país ajudou na construção de consensos e para colocar o G-20 $0^{18}$ em evidência. O Brasil mostrou grande capacidade de negociação multilateral ao contribuir decisivamente na tentativa de destravar a agenda da Rodada Doha em 2004. No âmbito do G-20, contribuiu para que o grupo atuasse de maneira mais articulada na OMC para definir as diretrizes e princípios da agenda da Rodada Doha. Tratou-se de um grande avanço na coordenação Sul-Sul.

O balanço da atuação do governo Lula nas negociações internacionais mostra grande capacidade de articulação e projeção do Brasil, mas mostra também que os avanços variam e que às vezes, a capacidade de influenciar os acontecimentos não é suficiente para

\footnotetext{
${ }^{18}$ O Grupo dos 20 (G-20), liderado por Brasil e Índia, foi criado em 2003 durante a preparação da Reunião Ministerial de Cancun para fazer oposição a um acordo entre EUA e EU que travava as negociações na OMC na questão da abertura agrícola. É formado por países africanos, asiáticos, latino-americanos e três desenvolvidos (Canadá, Austrália e Nova Zelândia).
} 
resolver impasses como divergências comerciais (as negociações nos âmbitos da OMC, Mercoul e Mercosul-União Européia sofreram muitos revezes).

A outra mudança que se destaca no governo Lula foi a forte preocupação em construir canais de diálogo com o setor produtivo e uma política industrial ativa, enfoques menos presentes nos governos FHC. Diniz e Boshi (2007) destacam que a escolha do governo do Partido dos Trabalhadores (PT) de ter José Alencar (senador e empresário de destaque do setor têxtil) como vice-presidente e a indicação de outros empresários para a equipe ministerial ${ }^{19}$, revelam a tentativa de aproximação com o empresariado. A estrutura institucional privilegiou a incorporação política do setor produtivo e a criação de novos fóruns de negociação, com o objetivo de acomodar interesses distintos e arquitetar consensos para implementar uma política industrial ativa. Nesses objetivos, estavam inseridas uma política de comércio exterior mais assertiva e diversificada e uma inserção do país mais autônoma na política internacional.

No plano comercial foram criados órgãos para apoio à competitividade do setor empresarial e consultas ao setor para subsidiar a política industrial, como o Conselho Nacional de Desenvolvimento Industrial - CNDI (2004) e a Agência Brasileira de Desenvolvimento Industrial - ABDI (2004). No plano das negociações de política externa, coube à CNI/CEB grande parte da interlocução do setor empresarial com o governo.

É importante observar que o empresariado apoiava o direcionamento do governo na busca de uma política industrial ativa, o estímulo ao comércio exterior e a ampliação dos canais de diálogo com o setor. Porém, notam-se críticas a aspectos econômicos como a taxa de juros e a alta carga tributária. Ressaltamos também, a discordância da $\mathrm{CEB} / \mathrm{CNI}$ e outras entidades e agentes do setor privado no enfoque Sul-Sul e de integração regional da política externa de Lula. Esses atores questionavam os reduzidos ganhos econômicos advindos de acordos com países do sul. (BEZERRA, 2008).

Cabe avaliar a atuação do setor empresarial, em particular da CNI, no contexto de da ampliação das negociações internacionais e de um modo de gestão voltado para a expansão dos canais de diálogo com o setor produtivo a indústria nacional.

\footnotetext{
19 Para compor o Ministério da Agricultura, foi indicado Roberto Rodrigues, presidente da ABAG Associação Brasileira de Agrobusiness e para compor o Ministério do Desenvolvimento da Indústria e Comércio Exterior, o empresário Luiz Fernando Furlan, então presidente do Conselho Administrativo da Sadia.
} 
A seguir, será avaliado o posicionamento da CNI e seus representantes acerca das questões de negociações internacionais da $\mathrm{OMC}$, do Mercosul e Mercosul-União Européia. Os dados coletados são oriundos de declarações de representantes da CNI noticiados pela imprensa (jornais Folha de São Paulo, Estado de São Paulo e Valor Econômico- período 2003-2010) e de documentos de posicionamento, estudos, notas técnicas e outros documentos emitidos pela CNI nesse período. 


\section{CAPÍTULO 4 - POSICIONAMENTO E EVOLUÇÃO DA PARTICIPAÇÃo EMPRESARIAL NAS QUESTÕES INTERNACIONAIS NO GOVERNO LULA}

\subsection{POSICIONAMENTO DA CNI SOBRE AS NEGOCIAÇÕES DO MERCOSUL (2003-2010)}

Sendo o Mercosul uma das prioridades da política comercial brasileira na década de 2000, a Confederação Nacional da Indústria passou a acompanhar as agendas interna e externa do bloco. Para tratar das questões sobre a integração do Mercosul, a CNI acompanha as negociações entre os governos do bloco, modera discussões no âmbito da CEB e representa a indústria brasileira no Foro Consultivo Econômico e Social (FCES) do Mercosul.

Já anteriormente à posse do então presidente eleito, Luis Inácio Lula da Silva, a CNI mostrava preocupações quanto aos rumos do Mercosul, sobretudo com a manifestação do futuro governo da intenção de priorizar o bloco como um dos focos centrais da política externa. No ano de 2002, a CNI elaborou um documento intitulado "A Indústria e o Brasil: uma agenda para o crescimento" ${ }^{20}$ para identificar a agenda da indústria no país, tendo em vista as eleições presidenciais em outubro do mesmo ano.

No documento, a entidade apresentou como desafios para o Mercosul a superação dos obstáculos para a consolidação da União Aduaneira, a eliminação de barreiras remanescentes ao comércio intrabloco, a implementação de uma política comercial comum com revigoramento da Tarifa Externa Comum (TEC), a eliminação das distorções regulatórias que afetavam a competição regional e, por fim, a adequação do quadro institucional de forma compatível com os objetivos de consolidação da União Aduaneira.

No início do governo Lula, o empresariado reconhecia que o Mercosul já havia sofrido certo desgaste nos anos anteriores. A coordenadora de Integração Internacional da Confederação Nacional da Indústria da época, Sandra Rios, detalhou os principais tópicos de um documento elaborado pela Coalizão Empresarial Brasileira e entregue ao presidente

\footnotetext{
${ }^{20} \mathrm{~A}$ produção do documento teve contribuições de empresários e organizações empresariais da indústria federações e associações setoriais. Foi realizada uma consulta direta a mais de 2.000 empresas de todo o País que identificou os principais temas e prioridades. Os Conselhos Temáticos da CNI desenvolveram a construção das recomendações e das propostas apresentadas no documento.
} 
eleito: "Há um Mercosul real, que ainda resiste ao total livre comércio, e o Mercosul dos acordos firmados" ${ }^{21}$, ela afirma, mostrando que o empresariado enxergava o Mercosul como um bloco em que nem todos os acordos firmados entre os quatro sócios são seguidos. Entretanto, a Confederação afirmava notar uma importância estratégica do Mercosul para o Brasil e recomendava que o país liderasse o processo de resgate da dimensão estratégica do projeto de integração, lançando as bases da consolidação e do aprofundamento da União Aduaneira.

Posteriormente, ao analisar as perspectivas do Mercosul após a Cúpula de Assunção, ocorrida em junho de 2005, a CNI afirma estar descontente com a imposição de medidas que significam indisciplina comercial no bloco e com o que chama de "marasmo na mesa de negociações" do processo de integração. Afirma que no período 2004-2006 têm-se muitos compromissos acordados, porém postergados, ou seja, houve avanços, mas havia muita limitação de alcance e dificuldades de implementação. ${ }^{22}$

Em documento publicado em agosto de 2005, ao retomar o histórico comercial intra-Mercosul, a CNI observa que os países do bloco vinham perdendo relevância como fornecedores do Brasil desde o ano de 2000. No caso da Argentina, em especial, observouse que o país realizava o dobro de importações oriundas do Mercosul em relação ao que o Brasil importava. Além disso, considerando o comércio bilateral entre os dois países, observou-se que o Brasil havia ganhado market share no mercado argentino nos últimos anos, enquanto os fornecedores argentinos perdiam progressivamente espaço no mercado brasileiro. $^{23}$

Segundo a CNI, essa dinâmica dos fluxos comerciais gerou nos países vizinhos a visão de que o Brasil é o país que mais se beneficia com o Mercosul, e que isso seria resultado de diferenças nas políticas cambiais e de incentivo às exportações do Brasil que estariam distorcendo as condições de competitividade. Assim, conforme a entidade, essa visão estimulou os membros do bloco a demandarem mecanismos de proteção ao setor produtivo e a proposta de criação de mecanismo de salvaguarda unilateral e automática,

\footnotetext{
${ }^{21}$ Empresários alertam Lula sobre as negociações no comércio exterior. O Estado de S. Paulo online, 16 de dezembro de 2002 D 20 Disponível $<$ http://www.estadao.com.br/arquivo/economia/2002/not20021216p42831.htm> Acesso em: 28 março 2011.

${ }^{22}$ CNI. Mercosul: as dificuldades da agenda interna e o avanço do comércio. Nota técnica. CNI: Agosto de 2005.p.1

${ }^{23}$ Id. Ibidem.
} 
especialmente por parte da Argentina, adotadas por razão de assimetrias na política industrial e variações das paridades cambiais.

A CNI assegura que a disparidade da taxa de câmbio entre as duas moedas não é o fator que explica o desempenho das exportações entre Brasil e Argentina até $2005^{24}$. O desempenho negativo da Argentina estaria, assim, associado à limitação das condições de oferta do país. Logo, o documento conclui que, enquanto a Argentina aguardava um entendimento para a adoção de um mecanismo de salvaguarda, prejudicou as exportações brasileiras com a implementação de medidas unilaterais de proteção à indústria doméstica.

No início do segundo mandato do governo Lula, a CNI realizou novamente uma revisão das estratégias brasileiras em relação ao Mercosul. Em documento publicado no ano de $2006^{25}$, a Confederação expõe o avanço do desempenho das exportações do Brasil ao bloco no período 2002-2004, estimulado pela desvalorização da taxa de câmbio real em 2002, pelo dinamismo da demanda externa dos Estados Unidos e China e pela adoção de medidas de estímulo às exportações como desoneração físcal e promoção comercial.

Todavia, conforme o documento, o "Boom exportador não reduz a necessidade de reforçar-se a política de comércio exterior. Processos em curso no cenário internacional como a emergência da China, as dificuldades vividas pelo multilateralismo e pelo Mercosul - indicam claramente a necessidade de discussão quanto a políticas na área de comércio exterior" ${ }^{26}$ Assim, a entidade apresenta mais críticas ao Mercosul, afirmando que o bloco sofre de "deficiência crônica" em relação ao processo de adoção e implementação das regras do jogo da integração. Um exemplo disso seria a resistência que os países membros têm em adotar as regras do bloco, sobretudo as que são percebidas como restrições à autonomia regulatória.

Segundo o documento, ainda, isso faz com que os empresários tenham dificuldade de integrar o Mercosul a suas estratégias de comércio e de investimento. A CNI ressalta a adoção de medidas unilaterais como um entrave ao Mercosul por gerarem baixa previsibilidade para os negócios e incerteza jurídica e regulatória. Por fim, a entidade defende o aperfeiçoamento dos mecanismos de implementação das decisões adotadas no

\footnotetext{
${ }^{24}$ A CNI demonstra que quando foi atingido o ápice da paridade peso-real em 2001, a balança comercial brasileira registrou déficit de 1,2 bilhão no comércio com a Argentina.Ibidem.

${ }^{25}$ CNI. Crescimento. A visão da indústria. Brasília: CNI, 2006.p.144.

${ }^{26}$ Id. Ibidem.
} 
Mercosul e, nos mercados da região, melhores condições de acesso para os produtos brasileiros comparativamente aos de terceiros países. É notório, portanto, por parte da CNI, um tom de criticidade ao bloco mais intenso em relação às declarações da entidade no início do governo Lula, já que ela recomenda agora que sejam revistas as estratégias brasileiras em relação ao Mercosul.

Ao longo da década de 2000, duas questões ainda iriam gerar um posicionamento de condenação ao Mercosul por parte da CNI: o processo de adesão da Venezuela ao bloco e o agravamento do contencioso comercial entre Brasil e Argentina.

Logo que é anunciada a intenção da adesão da Venezuela ao bloco, a CNI publica documentos demonstrando preocupações. O documento "Adesão da Venezuela ao Mercosul: agenda e interesses econômicos do Brasil”, publicado em janeiro de 2006 pela CNI, objetiva avaliar o significado do processo de adesão da Venezuela ao Mercosul (processo anunciado em dezembro de 2005 durante a XV Cúpula Ibero - americana). Ele chama atenção ao fato de que em um ano, de acordo com o Acordo de Complementação Econômica 59 (ACE 59) ${ }^{27}, 91,2 \%$ do fluxo comercial da Venezuela para o Brasil seria totalmente liberalizado, enquanto $63,6 \%$ das exportações brasileiras teriam livre acesso à Venezuela somente em até 14 anos. No documento, a CNI deixa claro sua contrariedade a esse cronograma de liberalização comercial: “(...) Há, portanto, uma evidente assimetria de tratamento nas preferências bilaterais" 28.

Em suma, a CNI reafirma a necessidade de "cautela" nas negociações do processo de adesão, para que "não haja prejuízo de um ambiente de estabilidade e clareza nas regras do jogo". Ressalta, com base no ACE 59, que a Venezuela "foi bastante cautelosa na concessão de benefícios para os produtos em que o Brasil é relativamente mais competitivo [...]" e que “[...] o processo de adesão da Venezuela ao Mercosul demanda revisão do

\footnotetext{
${ }^{27}$ O ACE 59 - acordo entre o Mercosul e a Comunidade Andina (CAN) é o acordo que estabelecia as regras das relações comerciais entre Venezuela e Brasil, assinado em dezembro de 2003. Trata-se de um Programa de Liberação Comercial para eliminar tarifas e outros direitos aduaneiros que serviu de base para a negociação da adesão da Venezuela ao Mercosul. Um dos focos de preocupação da CNI era de como se daria a Adesão da Venezuela ao ACE 18 (Acordo de complementação econômica $\mathrm{n}^{\circ} 18$ - que rege o comércio intra- Mercosul), visto que o ACE 59 continha prazos mais curtos e distintos de abertura para o Brasil e mais longos para a Venezuela.

${ }^{28}$ CNI. Unidade de Negociações Internacionais. Adesão da Venezuela ao Mercosul: agenda e interesses econômicos do Brasil. CNI: janeiro de 2006.p.5
} 
tratamento que aquele país concedeu aos produtos brasileiros no Programa de Liberalização Comercial". ${ }^{29}$

Na ocasião da oficialização da entrada da Venezuela no Mercosul, em julho de 2006, a CNI manifestou novamente ver poucas vantagens práticas nesse processo e, ainda, temor de um possível efeito negativo da adesão do país andino nas negociações do bloco com outros países (tinham receio de que o já difícil consenso entre Brasil, Argentina, Uruguai e Paraguai se tornasse ainda mais complicado com a entrada da Venezuela na hora de negociar acordos com a União Européia ou com os Estados Unidos). Logo, o empresariado temia que a presença venezuelana dificultasse acordos do Mercosul com outros países, como comprova a economista Lúcia Maduro, então analista de políticas e indústria da CNI: "A possibilidade de contaminação da agenda externa do Mercosul é o que preocupa os empresários brasileiros", ela afirmou. ${ }^{30}$

Lúcia Maduro também afirma na mesma reportagem que, na prática, o acordo iria alterar muito pouco as relações comerciais entre os dois países, já que o Brasil já tinha um elevado superávit comercial com a Venezuela, que no ano de 2006 superou os US\$ 2 bilhões: "O Brasil não precisa deste acordo para exportar. As vendas já aumentaram muito nos últimos anos", afirma. ${ }^{31}$ Pode-se concluir que esse é um dos motivos pelo qual a CNI se mostrou contrária à adesão da Venezuela. Dado o crescimento das exportações industriais brasileiras ao país até 2006, observou-se que a entrada da Venezuela no Mercosul não representava melhora substantiva nas condições de acesso dos produtos brasileiros ao mercado venezuelano em relação ao acordo de livre comércio (ACE-59), em vigor desde 2003.

$\mathrm{Na}$ visão da CNI, não havia muito interesse econômico para o Brasil incluir a Venezuela ao bloco a não ser pela integração energética, mas que dependia de questões regulatórias ainda a negociar. Sandra Rios afirmou em reportagem que o Mercosul já tinha acordo com a Comunidade Andina de Nações (CAN), feito em 2003, pelo qual a Venezuela

\footnotetext{
${ }^{29}$ Id. Ibidem. P.17.

${ }^{30}$ BACCOCINA, Denise. CNI teme que Chávez 'contamine' agenda do Mercosul. Folha de S. Paulo online, Brasília, 04 de julho de 2006. Disponível em: $<$ http://www1.folha.uol.com.br/folha/bbc/ult272u54742.shtml $>$ Acesso em: 28 março 2011.

${ }^{31}$ Id. Ibidem.
} 
já tinha o compromisso de livre comércio total com o Mercosul a partir de 2018. O ingresso da Venezuela ao Mercosul "só adiantou esse prazo para 2014", disse. ${ }^{32}$

Em outra declaração, o setor industrial criticou a forma e a velocidade com que a Venezuela foi aceita no Mercosul e se mostrou surpreendido pela adesão do país ao bloco: “O Mercosul já tem problemas suficientes, e não precisava de mais um. Não há convergência na política de comércio exterior da Venezuela e dos demais integrantes do Mercosul", salientou Sandra Rios em seminário realizado na CIESP, em 21 de junho de 2006. Para justificar tal análise, ela ponderou que a união dos países do Mercosul no aspecto econômico vinha ocorrendo no setor agrícola, onde os países detêm altíssima competitividade, situação exatamente oposta à da Venezuela, que além de não ter competitividade na agricultura, exige tarifas maiores para importação de manufaturados. Ela afirmou, por fim, que a Venezuela protege muito a agricultura e agroindústria, setores em que a posição dos demais sócios é ofensiva. ${ }^{33}$.

Para além das negociações com a Venezuela, na avaliação da CNI, embora o Brasil tenha aumentado suas exportações aos países do Mercosul, os outros membros do bloco obtiveram resultados mais positivos do que o país. Segundo o boletim de comércio exterior da CNI de dezembro de $2004^{34}$, os países da CAN (que inclui Peru, Equador, Venezuela, Bolívia e Colômbia) conseguiram maiores índices de acesso ao mercado brasileiro do que o Brasil conseguirá alcançar nestes países.

$\mathrm{O}$ documento relata que $86,5 \%$ das importações provenientes da Colômbia estarão livre do imposto de importação ao final do processo de abertura - cerca de cinco anos. Venezuela, Equador e Peru têm índices de 91,2\%, 98,6\% e 97,4\%, respectivamente. De outro lado, a abertura dos produtos brasileiros para esses países iria acontecer, em sua grande parte, entre seis e 15 anos. Segundo o documento, ainda, conforme publicado no jornal Folha de São Paulo, "Os setores industriais brasileiros com maiores interesses ofensivos nas negociações com a CAN têm expressado seu descontentamento com os resultados obtidos, considerando que as melhorias de condições

\footnotetext{
${ }^{32}$ Venezuela entrou cedo no Mercosul, avaliam especialistas. O Estado de S. Paulo online, 7 de dezembro de 2006. Disponível em: $<$ http://www.estadao.com.br/arquivo/economia/2006/not20061207p40264.htm > Acesso em: 28 março 2011.

${ }^{33}$ Representantes da indústria criticam política externa.O Estado de S. Paulo online, 21 de junho de 2006. Disponível em: $<$ http://www.estadao.com.br/arquivo/economia/2006/not20060621p36210.htm>Acesso em: 28 de março 2011.

${ }^{34}$ CNI.Informativo Comércio Exterior em Perspectiva. Ano 14, n. 3, dez.2004/jan.2005.
} 
de acesso a mercados para seus produtos serão muito limitadas" ${ }^{35}$. Isso demonstra novamente o desagrado da entidade industrial pelo fato dos acordos reservarem um tempo de abertura comercial mais longo para os produtos brasileiros que tem mais oportunidade de acesso aos mercados.

O contencioso comercial entre Brasil e Argentina foi outro tema que suscitou por diversas vezes a manifestação pública da CNI. Ele sempre esteve presente na agenda bilateral, mesmo antes da criação do Mercosul em 1991. A CNI avalia que toda vez que há uma crise econômica, a Argentina promove o acirramento de medidas protecionistas, iniciando uma nova onda de conflitos que envolve governos e os setores privados dos dois países.

Ao analisar o histórico do contencioso comercial, a entidade afirma que o fato de sempre os mesmos setores serem alvos de medidas protecionistas argentinas significa que o país não avançou na competitividade e modernização industrial como o Brasil. A segunda percepção da CNI sobre as causas do contencioso remete aos "reduzidos avanços do Mercosul na harmonização de políticas internas e instrumentos de defesa da concorrência" ${ }^{36}$, afirma a entidade em nota publicada em seu site.

Uma das fases mais graves do contencioso ocorreu com a Resolução 61/2009, de 4 de março de 2009, do Ministério de Produção da Argentina, que amplia a lista de produtos de exportação brasileira sujeita às licenças não-automáticas. Se em 2007 havia 58 produtos sujeitos a esse regime - dos setores de calçados, brinquedos e papel -, com as medidas adotadas em 2009 esse número passou para 199. Os setores de produtos têxteis como fios, tecidos e confecções, os produtos metalúrgicos e produtos para o lar (linha branca geladeiras, máquinas de lavar roupa, fogões, etc) foram os mais atingidos. A CNI elaborou nota técnica apontando que $13,5 \%$ do total exportado pelo Brasil para a Argentina foram atingidos pela medida, sendo que este percentual era de $3,7 \%$ em $2004 .{ }^{37}$

\footnotetext{
${ }^{35}$ RIBEIRO, Ana Paula. Parceiros do Mercosul conseguem acesso maior ao mercado brasileiro. Folha de $\mathbf{S}$. Paulo online, Brasília, 14 de dezembro de 2004. Disponível em: $<$ http://www1.folha.uol.com.br/folha/dinheiro/ult91u91677.shtml> Acesso em: 28 março 2011.

${ }_{36}$ CNI. Unidade de negociações Internacionais. Avaliação das medidas argentinas de restrição às exportações brasileiras. Nota técnica,CNI. Março de 2009.p.2

37 CNI. Medidas Unilaterais da Argentina: uma nova estratégia brasileira. CNI, Julho de 2009.p.3
} 
A ampliação do sistema de "valor critério" 38 por parte da Argentina também afetou as exportações do Brasil. A partir do primeiro semestre de 2009, os seguintes produtos brasileiros passaram a ter "preços de referência" para a Argentina: tubos de ferro e aço, tecidos de algodão, pastilhas, cintas de freio, pastilhas de freio montadas, sendo que 156 produtos foram afetados pela medida.

Segundo estudo da CNI, em 2008 o contencioso com a Argentina atingiu quase 11\% das exportações brasileiras, dos quais $4,8 \%$ das exportações foram afetadas pelo mecanismo de "valor critério", 1,4\% pelas medidas antidumping e salvaguardas e 4,6\% por licenças não automáticas. ${ }^{39}$

Diante desses fatos, o posicionamento declarado pela CNI foi de total repúdio às práticas comerciais adotadas pela argentina, alegando que essas medidas prejudicam a transparência e a previsibilidade nas relações comerciais e nas decisões de investimento.

Em nota publicada em julho de 2009, a Confederação afirma que, devido às medidas protecionistas argentinas, o Brasil perde market share nos produtos prejudicados enquanto a China amplia sua participação no mercado argentino nos mesmos produtos. ${ }^{40} \mathrm{~A}$ entidade fez duas sugestões ao governo: a primeira é a adoção de medidas de retaliação que podem ser licenças não automáticas nas importações brasileiras; a segunda, é que o governo abrisse um painel na OMC contra a Argentina. A CNI ressalta sua preferência pela utilização do sistema de solução de controvérsias, pois afirma que a primeira alternativa só aumentaria as incertezas negociais para as empresas brasileiras. ${ }^{41}$

A CNI também enviou carta em 16 de março de 2009 para o Ministro das Relações Exteriores em exercício, Celso Amorim, e para o Ministro do Desenvolvimento, Indústria e Comércio Exterior em exercício, Miguel Jorge, expondo sua insatisfação em relações às medidas adotadas pela argentina e solicitando apoio do governo para encontrar uma solução

\footnotetext{
${ }^{38}$ Sistema que rege as exportações do setor têxtil do Brasil para a Argentina. É uma medida unilateral adotada pelas aduanas argentinas aplicado para qualquer importação, inclusive as provenientes do Mercosul. Esse sistema estabelece um preço de referência para cada produto e exige que as importações realizadas abaixo desse nível sejam oneradas pela cobrança em dobro do Imposto do Valor Agregado (IVA) e outros impostos.

39 CNI. Unidade de negociações Internacionais. Avaliação das medidas argentinas de restrição às exportações brasileiras. Nota técnica,CNI. Março de 2009.p.1.

${ }^{40}$ Segundo dados da CNI, no período de janeiro a abril de 2009, comparativamente ao mesmo período de 2008, o market share Brasil no grupo de produtos atingidos por licenças não automáticas reduziu de $42 \%$ de para 31,5\%, enquanto a China expandiu sua participação de 21,5\% para 30,5\%. CNI. Medidas Unilaterais da Argentina: uma nova estratégia brasileira. CNI, Julho de 2009.p.3

${ }^{41}$ Id. Ibidem.
} 
adequada ao contencioso $^{42}$. Na carta, a entidade retoma as afirmações publicadas anteriormente em nota para a imprensa de que os prejuízos para os negócios se materializam de diversas formas: prejuízo econômico concreto (redução das exportações brasileiras); perda de market share de produtos brasileiros do mercado argentino; impacto negativo ao ambiente de negócios por conta do fator imprevisibilidade e reflexos negativos sobre o Mercosul ${ }^{43}$.

O episódio da aprovação do Mecanismo de Adaptação Competitiva (MAC) ${ }^{44}$, acordado entre Brasil e Argentina, em 2006, também incitou declarações da CNI, que participou ativamente da negociação: "O mecanismo contraria o espírito da integração do Mercosul e gera um clima de retrocesso no desenvolvimento do bloco", disse o presidente da CNI então em exercício, Armando Monteiro Neto. O acordo deixou de atender recomendações do setor produtivo brasileiro, que defendeu, por exemplo, a adoção de um mecanismo de natureza transitória. "Outra questão que preocupa é o desvio de comércio, que é uma coisa que nós precisamos estar atentos", afirmou Monteiro. ${ }^{45}$

Diante do desgaste do Mercosul, a partir da metade do segundo mandato do presidente Lula, o discurso do empresariado passa a enfatizar a flexibilização do bloco. Empresários presentes no $2^{\circ}$ Encontro Brasil-União Européia, no Rio de Janeiro, ocorrido em dezembro de 2008, afirmam que o Brasil vinha perdendo oportunidades de comércio bilateral com outros países em função de "amarras" do Mercosul e defendem que o país tenha liberdade para fechar acordos com mais independência do bloco. O então presidente da CNI, Monteiro Neto, também declarou ser à favor de uma maior "flexibilização" do Mercosul. Segundo ele, era preciso "estar mais desamarrado". Para Monteiro, a diplomacia comercial brasileira tinha "valorizado muito" o multilateralismo, mas ele precisava ser "mais pragmático". "Precisamos olhar nossos interesses e utilizar mais os acordos

42 CNI.Cartas número 089/2009 - PRES e 090/2009 - PRES. Brasília: CNI, 16 de março de 2009.

${ }^{43}$ CNI. Barreira Argentina prejudica exportações brasileiras. Nota para a imprensa. Brasília, 13 de março de 2009.

44 O MAC é um mecanismo aprovado entre Brasil e Argentina no dia $1^{\circ}$ de fevereiro de 2006 para "institucionalizar" uma salvaguarda intra-Mercosul. Poderá ser adotado caso um setor comprove que as importações do país vizinho são causa de dano a sua produção e não consiga fazer um acordo privado. As cotas aplicadas pelo país prejudicado poderão vigorar por prazo de um a três anos, podendo ser prorrogado por mais um ano.

${ }^{45}$ Para CNI, salvaguardas da Argentina geram retrocesso no Mercosul. Folha de S. Paulo online, 02 fevereiro 2006. Disponível em:< http://wwwl.folha.uol.com.br/folha/dinheiro/ult91u104872.shtml>Acesso em: 28 março 2011. 
bilaterais. O que nós constatamos hoje é que há países que vêm tendo dinamismo maior nas exportações justamente porque se utilizam mais de acordos bilaterais", disse Monteiro Neto. $^{46}$

Ao final do governo Lula, outra declaração de que o Mercosul dificulta a realização dos acordos bilaterais é feita em julho de 2010 - após discurso no $4^{\circ}$ Encontro Empresarial Brasil-União Européia, realizado pela entidade no Palácio do Itamaraty, em Brasília - pelo novo presidente da Confederação Nacional da Indústria, Robson Braga de Andrade, que avaliou que "Muito (dessa participação pequena do Brasil em acordos bilaterais) é porque tem que ser por meio do Mercosul. Isso tem dificultado um pouco os acordos". 47

De fato, o novo presidente da CNI, inicia seu mandato criticando o que entende como engessamento que o Mercosul impõe ao Brasil nas negociações de acordos comerciais internacionais: "Eu acho que nós estamos muito atrasados até por não poder fazer acordos fora do Mercosul. Questões políticas têm dificultado ações empresariais, sendo que nos negócios temos que ser muito mais ágeis do que nas negociações políticas" declara. ${ }^{48}$ Para Andrade, além das diferenças culturais entre os membros do bloco, os momentos econômicos distintos de cada país dificultavam negociações importantes como a com a União Européia.

Finalmente, a Confederação Nacional da Indústria, em documento publicado em $2010^{49}$, faz um balanço da situação do Mercosul. Afirma considerar o bloco como um espaço econômico importante para a indústria brasileira (importância devida ao aumento da participação nas exportações de produtos manufaturados e investimentos diretos de empresas brasileiras feitos ao bloco se analisada a última década como um todo). Entretanto, devido à redução da participação dos produtos brasileiros nos mercados

\footnotetext{
${ }^{46}$ Empresários querem Brasil mais independente do Mercosul. Folha de S. Paulo online, 22 de dezembro de 2008. Disponível em: $<$ http://wwwl.folha.uol.com.br/folha/bbc/ult272u482507.shtml $>$ Acesso em: 28 março 2011.

${ }^{47}$ FROUDE, Célia.Para CNI, Mercosul dificulta acordos bilaterais. O Estado de S. Paulo online, 14 de julho de 2010. Disponível em: <http://economia.estadao.com.br/noticias/not_27334.htm>Acesso em: 28 março 2011.

${ }^{48}$ RODRIGUES, Eduardo. Para CNI, Mercosul engessa negociações internacionais. O Estado de S. Paulo online, 17 de novembro de 2010. Disponível em: <http://economia.estadao.com.br/noticias/not_43738.htm> Acesso em: 13 de março de 2011.

${ }^{49}$ CNI .A indústria e o Brasil: uma agenda para crescer mais e melhor. Brasília:Confederação Nacional da Indústria, 2010.p.189.
} 
vizinhos nos últimos anos, em grande parte como efeito de medidas protecionistas adotadas pela Argentina, a entidade reafirma que um dos principais problemas do bloco continua sendo a baixa previsibilidade para as empresas e a incerteza jurídica e regulatória oriunda da dificuldade do cumprimento das normas pelos países - a "deficiência crônica" na implementação das regras do processo de integração.

A fragmentação de políticas econômicas domésticas e das estratégias de inserção internacional também são apontadas como fatores que dificultam o avanço na agenda externa do Mercosul, assim como as diferenças de prioridades nacionais e conflitos de interesses setoriais. A prioridade assinalada pela entidade em 2010, era que os membros do Mercosul adotassem posturas pragmáticas, para que os sócios do bloco pudessem apresentar ofertas diferentes e adotassem velocidades variadas nas negociações externas.

Dentre as recomendações para o futuro do bloco, a CNI incentiva a concentração dos esforços na completa implementação da área de livre comércio do Mercosul, removendo os entraves ainda existentes e evitando retrocessos que coloquem em questão a integração. Diante das dificuldades de integração do bloco, vê-se que em seu discurso de 2010, a entidade não prioriza mais a consolidação da União Aduaneira, como em declarações anteriores feitas em 2002, mas sim a consolidação da área de livre comércio, pois entende que esta não está completamente solidificada.

Por fim, a CNI também recomenda que o Brasil influencie as políticas econômicas dos demais países do bloco, buscando maior previsibilidade e segurança jurídica para os investimentos brasileiros na região e negocie a permissão para que os sócios adotem velocidades diferentes nas negociações externas do bloco. 


\section{CONSIDERAÇÕES FINAIS}

Pode-se considerar que houve avanços e retrocessos na trajetória do Mecosul desde sua criação em 1991. Dentre os avanços podemos citar progressos na operacionalização do sistema alfandegário intra-regional, a criação do Tribunal Permanente de Revisão para a resolução de conflitos em 2002 e a criação do Parlamento do Mercosul em 2005. Dentre os fatores negativos, destacam-se a existência de regimes de exceção como o automotivo, a imposição de cotas de importação de produtos brasileiros da chamada "linha branca" por parte do governo argentino, a falta de normas regionais acordadas no âmbito do bloco para inúmeras áreas como, por exemplo, barreiras técnicas, medidas sanitárias e fitossanitárias, salvaguardas, medidas antidumping, compras governamentais e propriedade intelectual e também as dificuldades quanto à internalização de normas pelos poderes legislativos dos países-membros.

Além disso, questões como a entrada da Venezuela no bloco, a aprovação do MAC e a falta de convergência das tarifas de cada país-membro para a Tarifa Externa Comum (processo de formação da União Aduaneira) também estão entre os fatores que prejudicaram o fortalecimento do Mercosul.

Ao analisar o posicionamento do empresariado brasileiro em relação ao Mercosul, no período 2003-2010, entende-se que ele tem a percepção de que o desenvolvimento dos negócios no bloco fica muito aquém do que se poderia esperar para um espaço econômico integrado. $\mathrm{O}$ fato de o setor ser contrário ao enfoque Sul-Sul da política externa do governo Lula reforça essa percepção. Tendo em vista as dificuldades apresentadas na integração econômica com os outros países-membros e na consolidação do bloco - além de disputas comerciais com Argentina - o efeito para o setor empresarial de desestímulo em relação ao bloco foi expressivo. Além das assimetrias na estrutura econômica e assimetrias de competitividade intra-bloco, a imprevisibilidade e a falta de respeito às regras foi um fatorchave para as percepções negativas do setor empresarial em relação ao Mercosul.

O setor passou a defender, assim, maior liberdade para as negociações comercias do Brasil, colocando o bloco como um entrave aos negócios. A CNI, nesse contexto, declara publicamente o estímulo à realização de acordos bilaterais fora do âmbito do 
Mercosul. Ao que tudo indica, o Mercosul perdeu prioridade para os empresários brasileiros progressivamente.

Entretanto, é notável a atuação da CNI na manifestação dos interesses do empresariado nas questões do Mercosul que geraram algum tipo de insatisfação ao setor. Um exemplo disso foi a grande quantidade de declarações públicas feitas pela CNI em documentos, notas técnicas expostas no site da entidade, declarações à imprensa ou feitas em congressos, reuniões e eventos, como observamos, emitindo o posicionamento do empresariado industrial nessas questões - sobretudo no caso da adesão da Venezuela ao Mercosul e no contencioso comercial do Brasil com a Argentina.

Nota-se que nesses casos, inclusive, a CNI teve muitas vezes um posicionamento distinto da posição do governo (a entidade criticou o governo por aceitar a criação da MAC, por fazer acordo permitindo a adesão da Venezuela e, além disso, o governo, seguindo as diretrizes políticas de fortalecimento da integração regional, não concordava em abrir um painel contra a Argentina no âmbito da OMC como recomendava a CNI).

À despeito da diminuição do interesse do empresariado pelo Mercosul, nota-se que o papel da CNI foi tanto de construir como de formalizar o posicionamento do empresariado industrial, com a intenção de que o setor fosse capaz de influenciar o processo negociador, ora defendendo seus interesses específicos em relação à Venezuela e avaliando oportunidades e custos para o Mercosul no projeto de alargamento do bloco; ora recomendando ao governo brasileiro que adotasse medidas contra a Argentina (abertura de painel no âmbito da $\mathrm{OMC}$ ) para resolução do contencioso comercial; ora recomendando a flexibilização do bloco para a realização de acordos bilaterais.

\subsection{POSICIONAMENTO DA CNI SOBRE AS NEGOCIAÇÕES NA OMC (2003 - 2010)}

Fundada em 1994 e sediada em Genebra, Suíça, a OMC tornou-se o principal fórum de discussão e estabelecimento de regras que regem o comércio multilateral. O objetivo da instituição é incentivar a liberalização comercial, aumentar os fluxos de comércio e impulsionar o desenvolvimento econômico dos países. A OMC incorporou as regras do 
Acordo Geral sobre Tarifas e Comércio de 1947 (o GATT) e reúne uma série de outros acordos e compromissos sobre temas variados relacionados ao comércio internacional.

O acompanhamento dos acordos de comércio multilateral negociados na OMC é importante para a CNI, já que tais acordos são elementos significativos para o aumento da participação do Brasil no comércio internacional. Dentre as últimas rodadas de negociação da OMC - Rodada Uruguai (1986-1994), que criou a OMC, e a Rodada de Doha que teve início em 2001 e ainda permanece em negociação, a CNI passou a monitorar o processo negociador desta segunda.

Ao longo da Rodada Doha o governo brasileiro teve a oportunidade de se afirmar como um dos interlocutores relevantes, exercendo um papel construtivo na apresentação de propostas que pudessem contribuir para a superação dos impasses. O setor industrial brasileiro participou ativamente desse processo, apresentando estudos técnicos e documentos de posição, que revelaram certo grau de flexibilidade para acomodar os custos que a ampliação da abertura comercial poderia gerar para os produtores nacionais.

Logo, do mesmo modo que acompanhou as negociações do Mercosul com o intuito de auxiliar na definição do posicionamento do empresariado nas negociações, a CNI realizou, no período do governo Lula, estudos, consultas técnicas ao setor privado e forneceu informações sobre diversos temas relativos à OMC. A entidade acompanhou as negociações dos principais temas de interesse do setor privado, como acesso a mercados para produtos agrícolas e não-agrícolas, serviços, regras de defesa comercial e facilitação de comércio, dentre outros. Além disso, promoveu e participou de reuniões técnicas com o empresariado e o governo, para haver o máximo de participação possível do setor privado no processo negociador como um todo, como veremos a seguir.

Em documento publicado pela CNI em $2002{ }^{50}$, a entidade afirmou que no âmbito da OMC, via como prioridade a negociação de regras e disciplinas comerciais. Em relação à Rodada Doha, afirmou ser essencial que as negociações da OMC conduzam a resultados equilibrados, com a melhora de acesso a mercados para os produtos exportados pelo Brasil, a eliminação das distorções nas regras comerciais e a necessária flexibilidade para acomodar as sensibilidades dos países em desenvolvimento.

\footnotetext{
${ }^{50}$ CNI. A indústria e o Brasil: uma agenda para o crescimento. Brasília: CNI, 2002.
} 
Em 14 de setembro de 2003, ocorre o chamado "fracasso de Cancun" - impasse na V Reunião Ministerial da OMC, em Cancun. Os "Temas de Cingapura" (investimentos, políticas de concorrência, transparência em compras governamentais e medidas de facilitação de comércio) causaram impasse nas negociações. Além disso, os Estados Unidos e a UE apresentaram uma proposta conjunta para as negociações agrícolas, o que gerou uma contraproposta imediata formulada pelo G-20, contribuindo para o embaraço nas negociações.

Apesar dos revezes na OMC, no início do segundo mandato de Lula, o governo centrava seus esforços nas negociações da Rodada Doha, diante das dificuldades de avançar em acordos regionais como o Mercosul. O empresariado dá apoio ao avanço das negociações da Rodada, pois alegava ter ciência da importância do fortalecimento das normas multilaterais de comércio para o Brasil, defendendo a negociação de regras comerciais claras, estáveis e o aperfeiçoamento do sistema de solução de controvérsias, importantes para a defesa dos setores exportadores brasileiros contra medidas de caráter eminentemente protecionista.

A CNI assinala, em documento publicado no ano de 2006, quatro considerações em relação à Rodada Doha:

as negociações agrícolas constituem o elemento crítico para o sucesso da Rodada e a avaliação dos benefícios obtidos pelo Brasil dependerá diretamente dos resultados dessas negociações; as negociações da Rodada devem gerar resultados equilibrados entre, de um lado, a agricultura, e de outro, a indústria e serviços; as negociações de produtos industriais devem permitir melhor acesso de produtos sujeitos a picos tarifários em países desenvolvidos; e as negociações de regras devem resultar no aperfeiçoamento dos procedimentos de aplicação de medidas antidumping, coibindo o uso das mesmas para fins protecionistas. ${ }^{51}$

Em relação à consideração de que agricultura e indústria devem ter resultados contrabalançados nas negociações, a CNI ressalta que desde as negociações multilaterais do GATT, passando para as da OMC, a tendência é de abertura do setor industrial, enquanto os setores agrícola e agroindustrial continuam recebendo elevado grau de proteção nos países desenvolvidos. A Confederação Nacional da Indústria defende que "não é aceitável que a

\footnotetext{
${ }^{51}$ CNI.Indústria defende negociação equilibrada na OMC.Nota. Brasília, 21 de junho de 2006. p.1
} 
rodada leve ao aumento das diferenças nas estruturas de proteção e nas regras atualmente vigentes para produtos industriais e agrícolas. ${ }^{52,}$

A CNI também destaca que o mandato de Doha determina que deveriam ser incorporados os princípios de tratamento especial e diferenciado para países em desenvolvimento e de reciprocidade assimétrica nas concessões a serem negociadas em acesso a mercados para bens industriais. A entidade declara: “É imprescindível que a Indústria brasileira possa contar com essas flexibilidades para acomodar os produtos sensíveis que terão dificuldades em adaptar-se aos cortes definidos pela fórmula que vier a ser acordada",53.

A Confederação também expõe considerações sobre o que deseja das negociações de regras referentes a produtos industriais na Rodada Doha:

O resultado final das negociações de produtos industriais (Nama - NonAgricultural Products Market Access) deve espelhar equilíbrio envolvendo os seguintes elementos: i) grau de consolidação de tarifas; ii) grau de ambição do corte resultante da fórmula (incluindo os coeficientes a serem aplicados); iii) tratamento para sensibilidades; e iv) período de implementação. Acordos setoriais não devem ser incluídos no conjunto de elementos para a avaliação dos compromissos a serem assumidos 54 .

Destacam-se, aqui, vários exemplos do trabalho da CNI para organizar e divulgar posicionamento do empresariado industrial referente à negociação de regras comerciais da OMC que afetam o setor. A entidade buscou influenciar o processo de negociação através de reuniões com representantes do governo, tentando inserir as demandas do setor empresarial na posição final do governo brasileiro nas negociações. Seguem listadas algumas das ações da CNI específicas da rodada de Doha, que configuram estudos, notas técnicas e documentos elaborados pela $\mathrm{CEB}$ que resultaram de reuniões com representantes do governo. Esses documentos foram disponibilizados pela entidade em seu site para a sociedade em geral:

\footnotetext{
${ }^{52}$. Id. Ibidem.p.1.

${ }_{53}^{53}$ Id. Ibidem.p. 1.

${ }^{54}$ Id. Ibidem.p.2.
} 
TABELA 2

Documentos e Relatórios da CEB sobre as negociações da OMC

\begin{tabular}{|c|c|}
\hline DOCUMENTO & SÍNTESE \\
\hline $\begin{array}{l}\text { Relatório NAMA } \\
\text { Autor:CEB } \\
26 \text { de Novembro de } 2004\end{array}$ & $\begin{array}{l}\text { O relatório, fruto da Reunião de } \\
\text { Coordenação Nacional entre o Ministério } \\
\text { das Relações Exteriores e o setor privado, } \\
\text { expõe um relato da reunião do NAMA } \\
\text { (Negociação de Acesso a Mercados para } \\
\text { Bens Não Agrícolas na OMC) ocorrida } \\
\text { entre 08 e } 11 \text { de novembro de } 2004 \text { em } \\
\text { Genebra. }\end{array}$ \\
\hline $\begin{array}{l}\text { Relatório reunião NAMA } \\
\text { Autor:CEB } \\
21 \text { de Outubro de } 2004\end{array}$ & $\begin{array}{l}\text { O relatório resume a pauta da reunião entre } \\
\text { governo e empresariado que teve como } \\
\text { objetivo preparar a reunião do grupo de } \\
\text { NAMA em Genebra ocorrida em 2004. De } \\
\text { modo geral, os debates centraram-se nos } \\
\text { aspectos técnicos das negociações de } \\
\text { NAMA. A coordenação da CEB havia } \\
\text { encaminhado na véspera ao governo, o } \\
\text { documento "Recomendações da CEB sobre } \\
\text { os temas que compõem o Anexo B do } \\
\text { Programa de Trabalho de Doha", que } \\
\text { recolhe as posições empresariais sobre os } \\
\text { diversos aspectos técnicos. }\end{array}$ \\
\hline $\begin{array}{l}\text { Relatório da } 3^{\text {a }} \text { Reunião do Grupo de } \\
\text { Trabalho sobre Facilitação de Comércio } \\
\text { Autor:CEB } \\
07 \text { de outubro de } 2004\end{array}$ & $\begin{array}{l}\text { O relatório resume a reunião entre o MRE e } \\
\text { o empresariado, coordenada pela Secretária } \\
\text { Maria Elisa Rabello Maia, Chefe Interina da } \\
\text { Divisão de Acesso a Mercados, com a } \\
\text { participação da Terceira Secretária Grace } \\
\text { Tanno, encarregada de acompanhar as } \\
\text { negociações sobre facilitação de comércio } \\
\text { na OMC e teve como objetivo dar } \\
\text { continuidade às discussões sobre o tema, } \\
\text { incorporado ao Programa de Trabalho da } \\
\text { Rodada de Doha, em julho de } 2008 \text {. }\end{array}$ \\
\hline $\begin{array}{l}\text { Erosão de preferências nas negociações de } \\
\text { NAMA } \\
\text { Nota técnica } \\
\text { Autor:CEB } \\
12 \text { de junho de } 2006 \text {. }\end{array}$ & $\begin{array}{l}\text { O documento explana a questão de que a } \\
\text { redução das tarifas de Nação Mais } \\
\text { Favorecida promove uma redução das } \\
\text { margens de preferências. Esse tema entrou } \\
\text { na agenda de negociações de NAMA e } \\
\text { vinha sendo alvo de propostas apresentadas } \\
\text { por países que representam dois grupos } \\
\text { distintos. }\end{array}$ \\
\hline
\end{tabular}




\begin{tabular}{|l|l|}
\hline $\begin{array}{l}\text { Bens remanufaturados e as negociações em } \\
\text { curso na OMC }\end{array}$ & $\begin{array}{l}\text { A nota explica o andamento do tema do } \\
\text { comércio de bens remanufaturados na } \\
\text { Rota Técnica }\end{array}$ \\
$\begin{array}{l}\text { Autor:CEB } \\
12 \text { de junho de 2006. }\end{array}$ & $\begin{array}{l}\text { do Brasil na OMC, que traduz a visão } \\
\text { tradicionalmente defendida por países em } \\
\text { desenvolvimento que que alcançaram } \\
\text { determinado nível de industrialização e que } \\
\text { se preocupam com os impactos da } \\
\text { importação de bens usados, a preços mais } \\
\text { reduzidos, sobre a indústria doméstica. }\end{array}$ \\
\hline
\end{tabular}

FONTE: CNI (2011)

Elaborado pela autora

Outro exemplo desse tipo de ação foi a reunião conjunta da Coalizão Empresarial Brasileira e FIESP com o Embaixador Roberto Carvalho de Azevêdo (Subsecretário-Geral de Assuntos Econômicos e Tecnológicos), realizada em São Paulo no dia 6 de junho de 2008, em que o setor privado debateu com o governo os principais dispositivos incorporados em versões revisadas dos textos sobre agricultura e bens industriais divulgados pela OMC, que serviriam de base para a fase final de negociações na Rodada Doha ${ }^{55}$.

Finalmente, mais um exemplo da busca pela inserção de seus interesses nas negociações é a indicação feita pelo setor industrial de um limite máximo de liberalização de importação de produtos industriais nas negociações da OMC. Para justificar esse índice, a indústria utiliza o argumento de que a Indústria brasileira vinha sendo exposta a crescentes pressões competitivas decorrentes do processo de valorização da moeda brasileira em relação às moedas dos principais parceiros comerciais e da emergência da China no comércio mundial. Além disso, afirma que a indústria continua penalizada por uma carga tributária elevada e crescente e por taxas de juros reais que estão entre as mais altas do mundo.

Sendo assim, nesse cenário, a Indústria considera que o limite máximo de liberalização suportável é o resultante da aplicação de um coeficiente 30 à fórmula Suíça ou coeficiente 1 à fórmula $\mathrm{ABI}$, o que significa uma redução tarifária média de 49\% nas tarifas brasileiras consolidadas na OMC. ${ }^{56}$

\footnotetext{
${ }^{55}$ CNI. OMC: é hora de concluir a Rodada Doha. Nota. Brasília: CNI, 06 de junho de 2008.

${ }^{56}$ CNI.Indústria defende negociação equilibrada na OMC Nota.Brasília, 21 de junho de 2006.
} 
Vê-se que a CNI mostrou-se capaz de inserir as demandas do setor empresarial na pauta do governo. Entre 2002 e 2004 ocorreram pleitos e vitórias brasileiras no âmbito do sistema de solução de controvérsias da $\mathrm{OMC}$, contra os Estados Unidos, na questão do algodão e contra a União Européia, na questão do açúcar. De acordo com a OMC, a prática de subsídios que o governo norte-americano tradicionalmente reeditava para seus fazendeiros de algodão provocou uma distorção artificial nos preços do produto, forçando sua queda no mercado internacional e prejudicando os produtores brasileiros. Em relação à disputa do açúcar, o próprio regime de açúcar da União Européia caminhava em direção oposta às regras da $\mathrm{OMC}$ em duas questões: acesso preferencial ao mercado europeu por parte de alguns países africanos, asiáticos e caribenhos e a exportação de um volume de açúcar subsidiado maior do que o permitido por tratados internacionais, dos quais a UE é signatária. Assim, foi comprovado que o regime açucareiro europeu fomentava a queda do preço mundial do produto e permitia a prática de subsídios excessivos.

Um dos motivos do êxito do Brasil no sistema de solução de controvérsias nesses embates ocorreu pela aliança formada pelo governo brasileiro e o setor empresarial agrícola. A Coalizão Empresarial Brasileira foi neste episódio uma das mais importantes arenas nas quais os empresários do agronegócio discutiram a inserção dos segmentos que representam nos mercados internacionais, conjuntamente, também, com a Confederação Nacional da Agricultura e Pecuária. (IGLÉCIAS, 2007).

Nesse sentido, a CNI apostava no sucesso da Rodada Doha para evitar o enfraquecimento do sistema multilateral do comércio e o domínio de iniciativas que provocam distorções nos fluxos de comércio internacional. Em nota publicada em 24 de julho de 2006, no contexto do fracasso de uma reunião de ministros do G-6 ${ }^{57}$ ocorrida uma semana antes em Genebra para tentar destravar a Rodada Doha, a CNI afirma: "O setor Industrial brasileiro continua acreditando que é importante salvar a Rodada de Doha. Para isso, sugere que o governo brasileiro continue trabalhando para a retomada dos entendimentos." 58

É certo, entretanto, que o setor empresarial já notava certo desgaste nas negociações da OMC em assuntos como protecionismo e subsídios. A CNI afirma em 2006, em

\footnotetext{
57 Grupo formado por Estados Unidos, União Européia, Brasil, Índia, Austrália e Japão.

${ }^{58}$ CNI. OMC: o fracasso da Rodada de Doha prejudica o Brasil Brasília, 24 de julho de 2006.
} 
documento: “[...] as negociações na OMC dificilmente garantirão um salto significativo nas condições de acesso aos mercados externos para as exportações brasileiras. Não é provável que a Rodada Doha resulte em redução substantiva nas barreiras incidentes sobre produtos de exportação do Brasil.", 59

Nos anos seguintes, o quadro geral das negociações da Rodada Doha foi de fracasso na tentativa de avanço na liberalização do comércio mundial. Foi intransponível a divergência entre os países mais industrializados e a maioria dos países emergentes frente a temas como o fim dos subsídios agrícolas e a abertura de mercados para bens e serviços. Em julho de 2008, a proposta de que Estados Unidos e Europa fizessem concessões no setor agrícola (reduzir a taxa de subsídios agrícolas e impor uma taxa limite a eles) e os países emergentes considerassem a abertura de seus mercados para bens industriais, não foi aceita principalmente pelas partes. ${ }^{60}$

Em reação ao impasse das negociações, Soraya Rosar, então consultora da Confederação Nacional da Indústria declara: "Não é uma boa notícia, de jeito nenhum... É triste ter perdido todos esses anos de trabalho. Para um pais emergente, não ter uma OMC forte, realmente é preocupante...O agronegócio brasileiro realmente é quem perde mais"61.

Em nota publicada em seu site, a CNI lamenta o fracasso da reunião ministerial de Doha:

O colapso da reunião enfraquece o sistema multilateral de comércio. Esse colapso representa prejuízo tanto para países desenvolvidos como para países em desenvolvimento. A ausência de um ambiente de abertura comercial previsível, que possa fazer frente à desaceleração econômica mundial e à atual crise de alimentos, e o risco da própria sobrevivência

\footnotetext{
${ }^{59}$ CNI. Crescimento. A visão da indústria. Brasília: CNI, 2006. p.149.

${ }^{60} \mathrm{Na}$ proposta apresentada, os EUA, entre outras coisas, se comprometiam a estabelecer um limite de US\$ 14,5 bilhões por ano para o subsídio doméstico a seus agricultores. A União Européia, por sua vez, aceitou reduzir $80 \%$ de seus subsídios domésticos para um limite máximo de US\$36 bilhões por ano. Em contrapartida, os países desenvolvidos pediram uma maior abertura dos mercados emergentes para seus produtos industrializados (com corte médio de tarifas de 54\%) e para os setores de bens e serviços públicos. Numa postura que causou grande desconforto entre os aliados no G-20 e no Mercosul, o Brasil aceitou a proposta. China e Índia, outros países de peso como Argentina e África do Sul se mantiveram contra a proposta.

${ }^{61}$ Veja a reação no Brasil após o fracasso das negociações da OMC. O Estado de S. Paulo, 29 de julho de 2008. Disponível em $:<\mathrm{http}: / /$ www.estadao.com.br/noticias/economia, veja-a-reacao-no-brasil-apos-ofracasso-das-negociacoes-da-omc,213916,0.htm>. Acesso em 25 de abril de 2011.
} 
das regras multilaterais de comércio representam um duro impacto para a economia internacional. ${ }^{62}$

O então presidente da CNI, Armando Monteiro Neto afirma que o Brasil tinha interesses ofensivos em produtos agrícolas e agroindustriais e que essas questões foram uma das que as que mais geraram entraves na Rodada Doha ${ }^{63}$. Para Monteiro, na época, o contexto de desaceleração da economia mundial e preocupações com as questões de segurança alimentar (elevação dos preços internacionais dos alimentos) só iriam contribuir para o fomento de iniciativas protecionistas e enfraquecimento da OMC. Tais iniciativas, afirmou, geralmente se concretizam em normas e regulamentos técnicos e sanitários a produtos e processos produtivos dos ramos agrícola, agroindustriais e da indústria em geral também.

Em artigo publicado no jornal O Estado de São Paulo, o então presidente da CNI, diante do fracasso da reunião de ministros ocorrida na sede da OMC em 2008, afirma que o Brasil deve focalizar em uma agenda pós-Doha: "Não podemos nos concentrar em tentar salvar a Rodada Doha. É desejável, mas as chances são reduzidas. [...] É hora de debater a agenda pós-Doha" ${ }^{64}$.

Vê-se, então, que, diante do fracasso da Rodada Doha, o empresariado fica desestimulado com as negociações ocorridas no âmbito da OMC e essa situação permanece nos anos subseqüentes.

Apesar da grande dificuldade na conclusão de acordos, ao final do governo Lula, a CNI divulga reconhecer o protagonismo do Brasil nas negociações comerciais multilaterais na Organização Mundial do Comércio nos últimos anos. A entidade mantém o trabalho de acompanhamento das negociações do organismo multilateral, mas não há otimismo acerca dos resultados das negociações.

As ações recomendadas pela CNI em relação à OMC em 2010 são:

a) Manter um sistema de monitoramento de novas barreiras criadas pelos principais parceiros comerciais e que afetem as exportações brasileiras;

\footnotetext{
${ }^{62}$ CNI.CNI lamenta fracasso da reunião ministerial de Doha. Nota. 30 de Julho de 2008. Disponível em:< http://www.cni.org.br/portal/data/pages>. Acesso em 13 de Abril de 2011

${ }^{63}$ NETO, Armando Monteiro.. É hora de debater a agenda pós-Doha. O Estado de S.Paulo, São Paulo,20 de agosto de 2008, Caderno B2 Economia, Opinião.

${ }^{64}$ Id.Ibidem.
} 
b) Exigir o cumprimento dos compromissos de regras de comércio que os parceiros comerciais assumiram na $\mathrm{OMC}$ ou em acordos bilaterais ou regionais com o Brasil; c) Negociar bilateralmente e/ou utilizar os foros de solução de controvérsias disponíveis nos diferentes acordos comerciais para remover novas barreiras comerciais e evitar o uso protecionista de medidas sanitárias e fitossanitárias ou de regulamentos técnicos. ${ }^{65}$

Por fim, a Confederação também defende a incorporação, no acordo sobre mudanças climáticas em negociação na $\mathrm{OMC}$, de mecanismos que previnam a introdução de barreiras comerciais nas legislações nacionais sobre mudanças climáticas; busca influenciar o debate na $\mathrm{OMC}$ sobre as relações entre regras comerciais e compromissos relacionados a mitigação e adaptação a mudanças climáticas; e busca também influenciar medidas que levem a China a cumprir os compromissos assumidos quando de sua acessão à OMC (a CNI acusa a China de demandar movimentos expressivos de liberalização de importações nos países em desenvolvimento, enquanto pleiteia tratamento especial com compromissos mais suaves por ter acedido recentemente à $\mathrm{OMC}$ e ainda estar em fase de implementação dos compromissos resultantes de seu processo de acessão). ${ }^{66}$

\section{CONSIDERAÇÕES FINAIS}

No período do governo Lula foram observados alguns resultados positivos nas negociações do país na OMC. O Brasil conseguiu obter vitórias relevantes no Mecanismo

\footnotetext{
${ }^{65} \mathrm{CNI}$.A indústria e o Brasil: uma agenda para crescer mais e melhor. Brasília:Confederação Nacional da Indústria, 2010.p.189.

${ }^{66}$ A transformação da China em player de primeira ordem no comércio internacional e sua entrada na OMC tendem a maximizar oportunidades e ameaças no campo comercial para o resto do mundo. A progressiva redução do saldo comercial obtido pelo Brasil em relação à China, preocupa as autoridades comerciais do país e empresários dos setores produtivos mais afetados pela aceleração das importações chinesas. Entre as principais causas desta tendência estariam: barreiras não-tarifárias praticadas pela China, tentativas de forçar a baixa de preços de produtos dos quais a China é grande exportadora, diferenças na política cambial (fixo na China e sobrevalorizado no Brasil), juros baixos e crédito abundante praticados pelos bancos estatais chineses, excessiva carga tributária e ineficiência da infra-estrutura do Brasil. Retirado de: PEREIRA, Lia Valls; FILHO, Galeno Tinoco Ferraz. O acesso da China à OMC: implicações para os interesses brasileiros. Brasília:CNI, Julho de 2005 Ref.: De acordo com o Contrato de Prestação de Serviços firmado entre a Confederação Nacional da Indústria - CNI e a Fundação Centro de Estudos do Comércio Exterior FUNCEX. Disponível em: $<$ http://www.cni.org.br/portal/data/files/8A9015D01418E1EE01142BE6153E02F2/ESTUDOS\%20CNI$5 \% 20 \mathrm{O} \% 20$ ACESSO $\% 20 \mathrm{DA} \% 20 \mathrm{CHINA} \% 20 \% \mathrm{C} 3 \% 80 \% 20 \mathrm{OMC} \% 20$ final $\% 20$ distribui $\% \mathrm{C} 3 \% \mathrm{~A} 7 \% \mathrm{C} 3 \% \mathrm{~A} 3$ o.pdf.> Acesso em: 02 de Abril de 2011.
} 
de Solução de Controvérsias (algodão e açúcar) e nas negociações da Rodada Doha mostrou capacidade de liderança (G-20) e de defesa de seus interesses. Entretanto, predominou nas negociações, a ausência de consenso, que envolveu, principalmente, questões relativas à acesso ao mercado de produtos agrícolas, produtos industriais e serviços, e a ajuda interna ao setor agrícola.

Em decorrência de falta de consenso, a suspensão das negociações da Rodada Doha por várias vezes implica riscos e incertezas e dentre estes, cabe mencionar o risco de maior protecionismo. Ademais, restrições nas negociações multilaterais tendem a estimular o progresso de acordos comerciais bilaterais.

Por esses fatores, ao analisar as declarações e documentos de posicionamento do empresariado industrial notamos que, ao final do período analisado, o setor tende a buscar outras iniciativas em relação ao comércio internacional, já que entende não ser prioridade concentrar-se na Rodada de Doha, diante dos inúmeros entraves ocorridos nas negociações.

Pelas declarações da entidade, vimos que o setor industrial brasileiro acreditou ser importante salvar a Rodada Doha e estimulou o governo brasileiro a aproveitar a liderança conquistada na Rodada e a continuar trabalhando para que essas negociações conduzam a resultados equilibrados que permitam maior acesso a mercados para produtos agrícolas exportados pelo Brasil, eliminação das distorções nas regras comerciais e níveis de abertura comercial condizentes com as necessidades da indústria brasileira. Entretanto, vê-se que o setor fica progressivamente desestimulado em relação à Doha, e remete à idéia de debater a agenda pós-Doha.

No período estudado, à despeito do andamento lento das negociações no âmbito da OMC, notou-se que a Confederação Nacional da Indústria realizou o acompanhamento das negociações da OMC pertinentes ao setor industrial, organizou o posicionamento do empresariado e o divulgou tanto ao governo (através de reuniões para inserir suas demandas nas negociações oficiais), como também ao público em geral, disponibilizando em seu site documentos sobre diferentes etapas e questões das negociações. Vale destacar, no entanto, que ao longo do período estudado, é visível a progressiva redução de documentos da entidade a respeito desse fórum de negociações. 


\subsection{POSICIONAMENTO DA CNI SOBRE AS NEGOCIAÇÕES MERCOSUL - UNIÃO EUROPÉIA (2003 - 2010)}

O início das negociações entre Mercosul e União-Européia deu-se com a assinatura do Acordo-Quadro de Cooperação Inter-Regional (1995). Os trabalhos se desenvolveram na forma de trocas de informações e estudos preliminares até o ano de 1999, quando em um encontro entre membros do Mercosul e da União Européia foram lançadas as bases para a negociação de um Acordo de Associação Inter-Regional. Em 24 de novembro do mesmo ano, durante a primeira reunião do Conselho de Cooperação, realizada em Bruxelas, foi criado o Comitê de Negociações Birregionais (CNB), que se reuniu pela primeira vez em abril do ano seguinte, em Buenos Aires. Nesta ocasião, o comitê criou três Grupos Técnicos para dar seguimentos aos futuros acordos: Econômico, Cultural e Social, e Técnico e Financeiro.

O governo brasileiro e o Mercosul, em geral, buscavam ampliar a exportação de seus produtos agrícolas e agroindustriais e, ao mesmo tempo, fazer uma contraposição às negociações da ALCA, que não progrediam.

Até o ano de 2001, as propostas negociadas não foram satisfatórias para ambas as partes. A União Européia ofereceu em julho de 2001, uma proposta tarifária que cobria cerca de $90 \%$ dos produtos industriais do Mercosul, porém deixava de fora produtos agrícolas. A CNI expõe em boletim ${ }^{67}$ a diferença no tratamento dos setores nessa proposta: grande abertura para os produtos industriais, setor em que a Europa é mais competitiva e já bastante aberta, em contrapartida de uma pequena redução de tarifas secundárias a um número limitado de produtos agrícolas e agroindustriais - de maior interesse Mercosul reforçando o protecionismo agrícola europeu.

A proposta do Mercosul, por sua vez, excluía $60,8 \%$ dos produtos importados da UE da oferta, na maior parte, bens industriais. A posição do Mercosul foi reforçada pela Argentina, que tinha um posicionamento contrário à entrada de produtos europeus, sobretudo no contexto de crise econômica pela qual passava.

Nos anos de 2002 e 2003 foram definidos cronogramas de trabalho para apresentação de propostas. As ofertas que ocorreram nesse período foram um pouco mais

\footnotetext{
${ }^{67}$ CNI. Comércio Exterior em Perspectiva. Ano 10, no 10 , Julho de 2001.
} 
flexíveis de ambos os lados, porém, ainda insatisfatórias para a conclusão de um acordo. As partes tinham interesse em chegar a um acordo, sobretudo com os constantes fracassos nas reuniões ministeriais no âmbito da OMC.

As negociações do ano seguinte confirmariam o difícil avanço na direção de um concerto entre os blocos. Em 21 de julho de 2004, o Mercosul suspendeu as negociações com a UE na tentativa de seu parceiro melhorar a oferta para os produtos agrícolas. O motivo da suspensão foi a proposta do bloco europeu para cotas aos produtos agrícolas (a proposta da União Européia era de que as cotas para a entrada de produtos de interesse do Mercosul como carnes, aves e etanol entrassem em vigor em dez anos).

Em nota, a CNI lamentou o episódio e prenunciou que, dada a temática complexa da pauta em debate, as negociações com a União Européia tinham grandes chances de ser intricadas: "Para diversos setores da indústria, ganhos significativos para a agricultura e a agro-indústria são importantes, porque se traduziriam em crescimento das exportações indiretas. A perspectiva de ganhos limitados nesta área - reforçada pelas características da oferta agrícolas apresentada nesta semana pela EU - constitui fonte adicional de frustração em relação ao acordo birregional”, ${ }^{\prime 68}$.

A CNI também assume ter receios na negociação entre Mercosul e União Européia, quanto à abertura do mercado nacional: "a abertura do mercado brasileiro à concorrência européia embute riscos consideráveis". Um desses riscos seria a abertura do mercado de bens entre as partes. A CNI defende que "esta abertura se desse de forma gradual, concedendo aos setores mais sensíveis tempo para o ajuste às novas condições de competição" ${ }^{69}$.

A indústria brasileira sugeriu uma série de regras comerciais com objetivo de aproveitar melhor as oportunidades do acordo Mercosul-UE e minimizar os riscos. A CNI afirmou, no entanto, que o fato de todas as questões permanecerem pendentes gerava incertezas no setor industrial acerca dos potenciais benefícios e riscos associados ao acordo.

\footnotetext{
${ }^{68}$ RIBEIRO, Ana Paula. Para CNI, suspensão de negociações com UE não significa ruptura. Folha de $\mathbf{S}$. Paulo online, 22 de Julho de 2004. Disponível em $<$ http://www1.folha.uol.com.br/folha/dinheiro/ult91u87025.shtml>; Acesso em 01 de Abril de 2011. O mesmo conteúdo está disponível em:

$<$ http://www.estadao.com.br/arquivo/economia/2006/not20060327p34257.htm> Acesso em 01 de Abril de 2011.

${ }^{60}$ Id. Ibidem.
} 
Nos meses seguintes, o setor industrial fez declarações que confirmavam o cenário de incertezas: "Não diria que estamos otimistas", afirmou Lúcia Maduro, economista da Unidade de Integração Internacional da CNI da época, que acompanhava as conversações. ${ }^{70}$ Do mesmo modo, Gilman Viana, presidente da CNA, afirma: "Mas o ambiente não está de muito otimismo, as negociações internacionais estão baseadas muito na postergação",71 .

É importante ressaltar que, para a CNI, a suspensão das negociações em 2004 não significava uma ruptura total, mas mostrava a complexidade do assunto. De fato, as questões que mais preocupavam a indústria eram o grau e a velocidade de abertura do Mercosul aos produtos industrializados europeus, a proposta européia de excluir do livre comércio itens produzidos com equipamentos que recebam isenção de imposto de importação e o estabelecimento das "regras de origem" dos produtos dos dois blocos.

Lúcia Maduro expõe que os interesses do setor do industrial no acordo MercosulUE estariam mais no sentido de proteger o mercado do Mercosul do que ampliar as relações comerciais: "Em termos de acesso a mercados, para nós, o mercado europeu já é bastante aberto. Então, quais seriam os ganhos? Existem sim, mas não posso dizer que eles sejam tão significativos como no caso da agricultura", diz Lúcia. "No caso da indústria, o mais importante é o acesso europeu ao Mercosul." ${ }^{, 72}$

Por causa da diferença de evolução industrial da Europa em relação ao bloco sulamericano, a indústria brasileira defendeu um cronograma de abertura mais lento e gradual. O setor pediu que o Mercosul não cedesse na sua proposta inicial, que estabelece grupos de produtos com prazos que teriam uma carência para entrar sem pagar imposto de importação no Mercosul. O Mercosul aceitava a liberação imediata para alguns produtos, mas queriam prazos de dois, oito e até dez anos para outros, enquanto os europeus pediam mais agilidade.

Em outubro de 2004, a União Européia entregou nova oferta de negociação ao Mercosul. A oferta incluía novamente o parcelamento em dez anos das cotas de exportação agrícola provenientes do Mercosul (o mesmo ponto que levou o Mercosul a suspender

\footnotetext{
${ }^{70}$ TORTORIELLO, Alexandre Mata.Chance de acordo com UE é 'remota', dizem agricultores. BBC Brasil online, São Paulo, 11de agosto de 2004.Disponível em:<

http://www1.folha.uol.com.br/folha/bbc/ult272u34162.shtml>. Acesso em 01 de Abril de 2011.

${ }^{71}$ Id.Ibidem.

${ }^{72}$ Id. Ibidem.
} 
negociações em julho do mesmo ano), o que fez os diplomatas brasileiros recuarem e levou a um impasse nas negociações outra vez. ${ }^{73}$

O setor privado ficou dividido com relação à atuação dos diplomatas brasileiros nas negociações com a União Européia. A CNI não apoiou a proposta, mas apoiou a posição do governo, bem como a continuidade das negociações, enquanto a Confederação da Agricultura e Pecuária do Brasil acusou os diplomatas brasileiros de terem "má vontade" em negociar com a Europa. ${ }^{74}$

Diante do desfecho insatisfatório das negociações no ano de 2004, a CNI resume seu posicionamento:

Os desafios eram, contudo, muitos. A oferta do Mercosul encontrou dificuldades para sua ampliação nos setores automotivo e têxtil e a européia na área agrícola, fazendo com que ambas fossem consideradas insuficientes pelas partes. Outras dificuldades relacionadas a condicionalidades de parte a parte e à necessidade de conclusão de entendimentos sobre um número expressivo de regras comerciais (regras de origem, drawback etc.) davam sinais sobre a impossibilidade de cumprimento da data de 31 de outubro. O setor privado brasileiro apoiou a estratégia do governo de prosseguir com as negociações além desta data 75 .

Entre 2006 e 2009, ocorreram anualmente Conferências do Foro Empresarial Mercosul-UE, para discutir o comércio no setor automotivo e o comércio agrícola, bem como o corte de alíquotas tarifárias, as quotas de exportação e o prazo de implementação das mudanças sugeridas a fim de que se chegassem a propostas para a retomada das negociações. Após quase seis anos de suspensão, sob protestos do setor agrícola, a União Européia decidiu em maio de 2010 retomar as negociações para um acordo de livre comércio com o Mercosul. A retomada das negociações foi decidida depois de quatro reuniões técnicas nos meses anteriores. O Mercosul incluiu nas propostas, o setor automotivo, e ampliou a oferta industrial para quase 90\%. A Argentina, também flexibilizou.

\footnotetext{
${ }^{73}$ SOLIANI, André. Para o Brasil, oferta européia é um "retrocesso" Folha de S. Paulo, Brasília, 01 de outubro de 2004. Disponível em: $<$ http://www1.folha.uol.com.br/folha/dinheiro/ult91u89526.shtml $>$. Acesso em 15 de abril de 2011.

${ }^{74}$ Id.Ididem.

${ }^{75}$ CNI. O Percurso do Mercosul em 2004. In.: Informativo Comércio Exterior em Perspectiva. Ano 14, n. 3,dez.2004/jan.2005.p.9
} 
O setor privado brasileiro reagiu bem à notícia. Alguns setores, como agronegócio e têxteis, querem aumentar as vendas para a Europa, apesar da crise que o continente atravessa. "Os benefícios de uma negociação desse porte são de longo prazo. O cenário será outro", disse Soraya Rosar. "A indústria precisa se internacionalizar e isso passa pela integração com as grandes economias", disse o diretor de relações internacionais da Federação das Indústrias do Estado de São Paulo (Fiesp), Mário Marconini. ${ }^{76}$

Em 2010, em documento publicado pela CNI, a entidade afirma ser preferência adotar uma agenda de negociações comerciais que tenha como prioridade a melhoria das condições de acesso a mercados relevantes para as exportações brasileiras. Além disso, afirma que de acordo com a pesquisa Prioridades da Agenda Comercial Brasileira, coordenada pela entidade, dentre os mercados prioritários para a negociação de acordos preferenciais, do ponto de vista empresarial, a União Européia está inclusa ${ }^{77}$.

Apesar dessas declarações mostrarem certo otimismo do empresariado com a retomada das negociações, é certo que no período que vai do final do primeiro mandato do governo Lula até quase o final do segundo mandato, predominou o impasse nas negociações e isso contribuiu para o arrefecimento do interesse da CNI no processo negociador como um todo. Até 2003, a disposição das lideranças da UE e do Mercosul na tentativa de concluir um acordo comercial suscitou trabalhos de consulta e estudos por parte da entidade. A percepção da impossibilidade do acordo e a paralização das negociações em 2004 provocou a redução de publicações e declarações da CNI sobre essa temática.

Por fim, é importante ressaltar a contribuição da CEB/CNI para o Ministério do Desenvolvimento, Indústria e Comércio Exterior (MDIC) e o Ministério das Relações Exteriores (MRE) durante as negociações entre União-Européia e Mercosul. A CEB e o MDIC criaram uma dinâmica cooperativa de trabalho em que identificavam os setores sensíveis na negociação. A CEB prestou auxílio ao MDIC na elaboração de listas tarifárias e o MDIC realizou consultas ao setor privado e as encaminhou ao MRE. O MRE,

\footnotetext{
${ }^{76}$ CHADE, Jamil; LANDIM, Raquel Europa volta a negociar acordo com Mercosul. O Estado de S.Paulo,05 de maio de 2010. Disponível em:

$<$ http://www.estadao.com.br/estadaodehoje/20100505/not_imp547124,0.php>. Acesso em: 02 de maio de 2011.

${ }^{77}$ CNI .A indústria e o Brasil: uma agenda para crescer mais e melhor. Brasília:Confederação Nacional da Indústria, 2010.p.189.
} 
reconhecendo a articulação do MDIC com o setor privado e com outros ministérios, apoiou-se em seu trabalho para as negociações. ${ }^{78}$

\section{CONSIDERAÇÕES FINAIS}

Diversos fatores contribuíram para o impasse nas negociações do Mercosul com o bloco europeu. Um dos principais objetivos do Mercosul era ampliar a exportação de produtos agrícolas e este foi ponto principal de resistência da União Européia. Destaca-se, também, as diferenças econômicas e de posicionamento de alguns membros do Mercosul, que ocasionaram dificuldades quanto à definição da posição oficial do bloco e coordenação de interesses.

A União Européia, por sua vez, além de apresentar forte resistência em relação à liberalização de produtos agrícolas e agroindustriais, tem, no fracasso da ALCA, um fator que contribui para uma menor motivação nas negociações, visto que para o bloco europeu, um dos objetivos em fazer o acordo com o Mercosul, era contrapor a formação da ALCA.

Em geral, o posicionamento da CEB apresentou convergência com a posição do governo brasileiro nas negociações. Até 2004, enquanto as negociações ainda estavam em andamento, a CNI realizou consultas ao setor privado e definiu posicionamento sobre as questões em pauta de negociação. As declarações de representantes da CNI apontaram para uma postura defensiva do setor industrial em relação a entrada de bens industriais europeus, mostrando interesse em ampliar o mercado para alguns setores industriais exportadores, como o automotivo, o têxtil e o de calçados, enquanto o setor agrícola buscava abertura européia a seus produtos. A CEB, sendo um dos instrumentos de vocalização do setor empresarial, embora seja uma instituição criada no âmbito da Confederação da indústria, também teve articulação com o setor agrícola e agro-industrial para dialogar com o governo. Destacou-se assim, o papel da CEB/CNI em dialogar com o setor privado.

O período como um todo mostra gradual redução de declarações da CNI/CEB sobre as negociações, conseqüência do longo período de travamento das negociações.

\footnotetext{
${ }^{78}$ BEZERRA, Vicente Amaral. Participação de grupos empresariais em negociações comerciais: o caso das negociações entre Mercosul e União Européia (2001-2004). Dissertação (Mestrado em Ciências Sociais)Universidade de Brasília, Brasília, 2008.
} 


\section{CONCLUSÃO}

Ao analisar o histórico da representação empresarial no Brasil, observamos que em contraposição à literatura que avalia o empresariado nacional como um setor sem organização coletiva e sem atuação política significativa, sobretudo em relação às negociações internacionais, uma linha de argumentação distinta diagnosticou uma inflexão nessa trajetória com a criação da CEB nas negociações da ALCA, momento em que o empresariado, de forma independente, passou a ter agenda e posicionamento.

Nos primeiros anos do governo Lula, a ampliação das relações internacionais e a aproximação do governo com o setor empresarial através de fóruns e outros canais de diálogo, somadas às expectativas de o Brasil angariar benefícios comerciais com o acordo de livre comércio Mercosul - União Européia, com a possível retomada do Mercosul e com o possível avanço na batalha contra os subsídios agrícolas e ampliação de trocas comerciais nas negociações da Rodada Doha, conferiram certo otimismo ao empresariado.

Assim, através da análise das declarações e documentos e emitidos pela CNI, notase que a formulação de agenda e posicionamento foi mantida neste primeiro momento. Acompanhamos a vasta quantidade de documentos de posicionamento, relatórios, estudos, publicações, notas técnicas e declarações à imprensa emitidos pela entidade acerca de diversos episódios das negociações nos âmbitos da OMC, Mercosul e Mercosul-União Européia. Fica claro, portanto, a importância da entidade na organização do posicionamento do empresariado frente às questões internacionais e na sua divulgação às instâncias negociadoras.

A CEB, em particular, contribuiu nas tentativas (nem sempre bem-sucedidas) de inserir algumas demandas do setor empresarial nas pautas de negociação através consultas ao empresariado e de reuniões com órgãos do governo para divulgar o posicionamento do setor. Mesmo discordando de alguns aspectos políticos das negociações, a CEB subsidiou a posição do governo nas negociações internacionais através de estudos técnicos, mostrando capacidade de ação coletiva do empresariado e estreitamento de vínculos com os centros decisórios do país. 
Vimos também, a importância da CEB na articulação do posicionamento de outros setores empresariais distintos da indústria, como, por exemplo, no caso dos contenciosos comerciais na $\mathrm{OMC}$ em que a Coalizão dialogou com o empresariado agrícola, o que mostra sua capacidade de aglutinar interesses dos diversos setores produtivos.

Destaca-se que, por vezes, a CNI fez oposição às posturas do governo publicamente e fez declarações com posicionamento contrário ao do governo em relação às negociações internacionais. Isso demonstra uma estratégia política própria e independente do empresariado frente às relações comerciais internacionais ao longo do período dos mandatos do governo Lula.

Contudo, ao longo do período 2003-2010, nota-se que diante do arrefecimento das negociações nos âmbitos da OMC, Mercosul e Mercosul-UE, devido às diversas dificuldades já enumeradas e constantes impasses nas mesas de negociação, foi nítido o gradual desestímulo do setor empresarial pelas negociações. Isso foi comprovado nas declarações emitidas por representantes da CNI, bem como pela redução de material publicado sobre algumas negociações.

A não verificação das expectativas de ganhos reais e a ausência de resultados concretos nessas negociações internacionais foi fator de grande contribuição para a insatisfação do setor empresarial relativas à política externa do governo Lula. Há também a hipótese de que o setor teve a percepção de que as iniciativas comerciais nas negociações exteriores brasileiras e de integração comercial regional desse governo estavam mais focadas na projeção regional e mundial do Brasil (como líder dos países em desenvolvimento) e para a política externa brasileira orientada para o multilateralismo, do que focada nos ganhos comerciais.

Ora, o fato de o empresariado engajar-se e manifestar-se inicialmente em relação às negociações, com mais ênfase, ainda, nas questões em que divergiam do governo brasileiro ou nas que tinham mais interesse, e, posteriormente, reduzir suas manifestações e participação na medida em que as negociações foram apresentando impasses, indica que a capacidade de ação política do setor é evidente, mas que, entretanto, ele só se mobiliza quando há interesse e incentivos reais.

Os objetivos da pesquisa em analisar a atuação da Confederação Nacional da Indústria acerca das principais arenas negociações internacionais do Brasil no período 
2003-2010 foram alcançados. A pesquisa avançou no mapeamento e na compreensão do posicionamento do empresariado nacional em relação às negociações internacionais do Brasil nesse recorte temporal.

Confirma-se o papel da CEB/CNI na ampliação da interlocução entre governo e empresariado, e, ainda, confirma-se a capacidade do empresariado se organizar coletivamente e definir posicionamentos, desde que entenda que há motivação para tal.

Apontando para novas pesquisas, a identificação da redução da atuação da CEB/CNI nas negociações internacionais abre espaço à projeção de novas entidades empresariais que representem os interesses do empresariado nessas negociações, aglutinando interesses dos diversos setores produtivos ou representando-os setorialmente. 


\section{REFERÊNCIAS BIBLIOGRÁFICAS}

BACCOCINA, Denise. CNI teme que Chávez 'contamine' agenda do Mercosul. Folha de S. Paulo online, Brasília, 04 de julho de 2006. Disponível em:< http://www1.folha.uol.com.br/folha/bbc/ult272u54742.shtml> Acesso em: 28 março 2011.

BEZERRA, Vicente Amaral. Participação de grupos empresariais em negociações comerciais: o caso das negociações entre Mercosul e União Européia (2001-2004). Dissertação (Mestrado em Ciências Sociais)-Universidade de Brasília, Brasília, 2008.

BIANQUI, Álvaro. Crise e representação empresarial: o surgimento do pensamento nacional das bases empresariais. Revista de Sociologia Política, Curitiba, n.16, p. 123-142, 2001.

BOSCHI, Renato. Elites Industriais e Democracia. Rio de Janeiro: Editora Graal, 1997.

CHADE, Jamil; LANDIM, Raquel Europa volta a negociar acordo com Mercosul. O Estado de S.Paulo,05 de maio de 2010. Disponível em:

<http://www.estadao.com.br/estadaodehoje/20100505/not_imp547124,0.php>. Acesso em: 02 de maio de 2011.

COALIZÃO EMPRESARIAL BRASILEIRA. Bens remanufaturados e as negociações em curso na OMC. Nota Técnica. Brasília, 12 de junho de 2006.

CEB. Contribuições do Setor Empresarial Brasileiro para Negociações da ALCA. CEB: março de 1999.

CEB. Erosão de preferências nas negociações de NAMA. Nota técnica. Rio de Janeiro: CEB,12 de junho de 2006.

CEB Negociações de Acesso a Mercados para Bens Não-Agrícolas na OMC (NAMA). Reunião de Coordenação Nacional. Relatório. Brasília: CEB, 21 de Outubro de 2004.

CEB. Negociações de Acesso a Mercados para Bens Não-Agrícolas na OMC (NAMA). Reunião de Coordenação Nacional. Relatório. Brasília: CEB, 26 de Novembro de 2004.

CEB. Relatório da $3^{\text {a }}$ Reunião do Grupo de Trabalho sobre Facilitação de Comércio. Brasília: CEB, 07 de outubro de 2004.

CONFEDERAÇÃO NACIONAL DA INDÚSTRIA. A Coalizão Empresarial Brasileira e a Rodada do Milênio. Comércio Exterior em Perspectiva. Brasília: CNI, ago. 1999.

CNI .A indústria e o Brasil: uma agenda para crescer mais e melhor. Brasília: Confederação Nacional da Indústria, 2010. 
CNI. A indústria e o Brasil: uma agenda para o crescimento. Brasília:CNI, 2002.

CNI. As negociações internacionais do Brasil. Comércio Exterior em Perspectiva. Brasília: CNI, nov. 2000.

CNI. Barreira Argentina prejudica exportações brasileiras. Nota para a imprensa. Brasília: CNI, 13 de março de 2009.

CNI.Cartas número 089/2009 - PRES e 090/2009 - PRES. Brasília: CNI, 16 de março de 2009.

CNI. Crescimento. A visão da indústria. Brasília: CNI, 2006. p.149.

CNI. Comércio Exterior em Perspectiva. Ano 10, nº 10 , Julho de 2001.

CNI.Indústria defende negociação equilibrada na OMC Nota.Brasília: CNI, 21 de junho de 2006.

CNI.Informativo Comércio Exterior em Perspectiva. Ano 14, n. 3, dez.2004/jan.2005.

CNI.CNI lamenta fracasso da reunião ministerial de Doha. Nota. CNI: 30 de Julho de 2008. Disponível em:< http://www.cni.org.br/portal/data/pages $>$. Acesso em: 13 de Abril de 2011.

CNI. Mecanismos de consulta CNI. Brasília: Confederação Nacional da Indústria, 2009.26 p.

CNI. Mercosul: as dificuldades da agenda interna e o avanço do comércio. Nota técnica. CNI: agosto de 2005

CNI. Medidas Unilaterais da Argentina: uma nova estratégia brasileira. CNI: julho de 2009.

CNI. OMC: é hora de concluir a Rodada Doha. Nota. Brasília: CNI, 6 de junho de 2008.

CNI. OMC: o fracasso da Rodada de Doha prejudica o Brasil. Brasília: CNI, 24 de julho de 2006.

CNI. Unidade de Negociações Internacionais. Adesão da Venezuela ao Mercosul: agenda e interesses econômicos do Brasil. CNI: janeiro de 2006.

CNI. Unidade de negociações Internacionais. Avaliação das medidas argentinas de restrição às exportações brasileiras. Nota técnica,CNI: março de 2009.p.1.

CNI. O Percurso do Mercosul em 2004. In.: Informativo Comércio Exterior em Perspectiva. Ano 14, n. 3,dez.2004/jan.2005.p.9 
CNI teme que Chávez 'contamine' agenda do Mercosul. Folha de S. Paulo online, 04 de julho de 2006. Disponível em:<

http://www1.folha.uol.com.br/folha/bbc/ult272u54742.shtml> Acesso em: 28 março 2011.

Coordenadores europeus e do Mercosul suspendem conversações. Valor Econômico online, 21 de Julho de 2004. Disponível em:<

http://www.valoronline.com.br/online/economia/92/177893/coordenadores-europeus-e-domercosul-suspendem-conversacoes $>$. Acesso em 02 de Março de 2011.

CRUZ, Sebastião C. Velasco e. Empresários e o regime no Brasil : a campanha contra a estatização. São Paulo. Tese (doutorado em Ciência Política). Universidade de São Paulo, 1978.

DINIZ, Eli. A busca de um novo modelo econômico: padrões alternativos de articulação público-privado in Dossiê Estado e Política Econômica na América Latina. Revista de Sociologia Política, Curitiba, 14, pp. 7-28, 2000.

DINIZ, Eli. Empresariado, Estado e Políticas Públicas no Brasil: novas tendências no limiar do novo milênio. Publicação eletrônica, Rio de Janeiro, v. 1, p. 1-30, 2004.

DINIZ, Eli. Empresariado e Transição Política no Brasil: Problemas e Perspectivas. Dados, Rio: IUPERJ, nº 22, fevereiro 1984.

DINIZ, Eli. Empresariado e Estratégias de Desenvolvimento. Lua Nova, São Paulo n. 5556, p.242- 261, 2002.

DINIZ, Eli. Neoliberalismo e corporativismo : as duas faces do capitalismo industrial no Brasil. Revista Brasileira de Ciências Sociais, Rio de Janeiro, ano 7, n. 20, pp. 31-46, 1992.

DINIZ, Eli; BRESSER-PEREIRA, Luiz Carlos. Empresariado Industrial, Democracia e Poder Político. Novos Estudos CEBRAP, n.84, p.83-99, 2009.

DINIZ, Eli; BOSCHI, Renato R. A difícil rota do desenvolvimento: Empresários e a Agenda Pós-Neoliberal. Belo Horizonte: Editora UFMG; Rio de Janeiro: Editora IUPERJ, 2007.

Empresários alertam Lula sobre as negociações no comércio exterior. O Estado de S. Paulo online, 16 de dezembro de 2002. Disponível em : $<$ http://www.estadao.com.br/arquivo/economia/2002/not20021216p42831.htm> Acesso em: 28 março 2011.

Empresários querem Brasil mais independente do Mercosul. Folha de S. Paulo online, 22 de dezembro de 2008. Disponível em:<

http://www1.folha.uol.com.br/folha/bbc/ult272u482507.shtml>Acesso em: 28 março 2011. 
FROUDE, Célia.Para CNI, Mercosul dificulta acordos bilaterais. O Estado de S. Paulo online, 14 de julho de 2010. Disponível em:

$<$ http://economia.estadao.com.br/noticias/not_27334.htm>Acesso em: 28 março 2011.

IGLÉCIAS, Wagner. O empresariado do Agronegócio no Brasil: ação coletiva e formas de atuação política - As batalhas do açúcar e do algodão na OMC. Rev. Sociol. Polít., Curitiba, 28, p. 75-97, jun. 2007.

MANCUSO, W. P. O empresariado como ator político no Brasil: balanço da literatura e agenda de pesquisa. Revista de Sociologia e Política, Curitiba, v. 28, pp. 131- 146, 2007.

MANCUSO, Wagner Pralon; OLIVEIRA, Amâncio Jorge de. Abertura Econômica, Empresariado e Política: Os Planos Doméstico e Internacional. Lua Nova, São Paulo, n. 69, p.147-172, 2006.

MANCUSO, W.P. O Lobby da Indústria no Congresso Nacional: empresariado e política no Brasil contemporâneo. Tese (doutora do em Ciência Política). Universidade de São Paulo, São Paulo, 2004.

MATHIAS, M. Sob o prisma dos interesses: a política externa brasileira e a Confederação Nacional da Indústria. 2011. Tese (Doutorado em Ciência Política) - Instituto de Filosofia e Ciências Humanas, Universidade Estadual de Campinas, Campinas, 2011.

NETO, Armando Monteiro. É hora de debater a agenda pós-Doha. O Estado de S.Paulo, São Paulo,20 de agosto de 2008, Caderno B2 Economia, Opinião.

Negociação entre União Européia e Mercosul fracassa. Valor Econômico online, 21 de outubro de 2004. Disponível em:

$<$ http://www.valoronline.com.br/search/apachesolr_search/CNI\%20MERCOSUL\%20UNI AO $\% 20$ EUROPEIA? page $=40 \&$ solrsort $=$ created $\% 20 \mathrm{desc}>$. Acesso em 02 de Março de 2011.

OLIVEIRA, A. J. S. N. O papel da coalizão empresarial brasileira e as negociações da ALCA. Tese (doutorado em Ciência Política). Universidade de São Paulo, São Paulo, 2003.

OLSON, Mancur. The Logic of Collective Action: Public Goods and the theory of groups. Cambridge, MA: Harvard University Press, 1971.

ONUKI, Janina. O Governo e o empresariado argentino: a percepção política do Mercosul. Dissertação (mestrado em Ciência Política). Universidade de São Paulo: DCP/USP, 1996.

Para CNI, Mercosul dificulta acordos bilaterais. O Estado de S. Paulo online, 14 de julho de 2010. Disponível em: <http://economia.estadao.com.br/noticias/not_27334.htm>Acesso em: 28 março 2011. 
Para CNI, Mercosul engessa negociações internacionais. O Estado de S. Paulo online, 17 de novembro de 2010. Disponível em:

$<$ http://economia.estadao.com.br/noticias/not_43738.htm> Acesso em: 13 março 2011.

Para CNI, salvaguardas da Argentina geram retrocesso no Mercosul. Folha de S. Paulo online, 02 fevereiro 2006. Disponível em: $<$

http://www1.folha.uol.com.br/folha/dinheiro/ult91u104872.shtml>Acesso em: 28 março 2011.

PEREIRA, Lia Valls; FILHO, Galeno Tinoco Ferraz. O acesso da China à OMC: implicações para os interesses brasileiros. Brasília:CNI, Julho de 2005. Ref.: De acordo com o Contrato de Prestação de Serviços firmado entre a Confederação Nacional da Indústria - CNI e a Fundação Centro de Estudos do Comércio Exterior - FUNCEX. Disponível em:

$<$ http://www.cni.org.br/portal/data/files/8A9015D01418E1EE01142BE6153E02F2/ESTUD OS\% $\% 20 \mathrm{CNI}-$ 5\%20O\%20ACESSO $\% 20$ DA $\% 20$ CHINA $\% 20 \%$ C3\%80\%20OMC $\% 20$ final $\% 20$ distribui $\%$ C3\%A7\%C3\%A3o.pdf.> Acesso em: 02 de Abril de 2011.

Representantes da indústria criticam política externa.O Estado de S. Paulo online, 21 de junho de 2006. Disponível em:<

http://www.estadao.com.br/arquivo/economia/2006/not20060621p36210.htm>Acesso em: 13 de março 2011.

RIBEIRO, Ana Paula. Para CNI, suspensão de negociações com UE não significa ruptura. Folha de S. Paulo online, 22 de Julho de 2004. Disponível em $<$ http://www1.folha.uol.com.br/folha/dinheiro/ult91u87025.shtml>; Acesso em 01 de Abril de 2011. Mesmo conteúdo está disponível em:

$<$ http://www.estadao.com.br/arquivo/economia/2006/not20060327p34257.htm> Acesso em 01 de Abril de 2011.

RIBEIRO, Ana Paula. Parceiros do Mercosul conseguem acesso maior ao mercado brasileiro. Folha de S. Paulo online, Brasília, 14 de dezembro de 2004. Disponível em:< http://www1.folha.uol.com.br/folha/dinheiro/ult91u91677.shtml> Acesso em: 28 março 2011.

RODRIGUES, Eduardo.Para CNI, Mercosul engessa negociações internacionais. O Estado de S. Paulo online, 17 de novembro de 2010. Disponível em: $<$ http://economia.estadao.com.br/noticias/not_43738.htm> Acesso em: 13 de março de 2011.

SOLIANI, André. Para o Brasil, oferta européia é um "retrocesso" Folha de S. Paulo online, Brasília, 01 de outubro de 2004. Disponível em:< http://www1.folha.uol.com.br/folha/dinheiro/ult91u89526.shtml>. Acesso em 15 de abril de 2011. 
TORTORIELLO, Alexandre Mata.Chance de acordo com UE é 'remota', dizem agricultores. BBC Brasil online, São Paulo, 11de agosto de 2004.Disponível em:< http://www1.folha.uol.com.br/folha/bbc/ult272u34162.shtml>. Acesso em 01 de Abril de 2011.

VEIGA, João Paulo Candia. As Negociações Comerciais do Governo Lula. Revista Brasileira de Comércio Exterior, Rio de Janeiro, n. 83 - Abril - Junho de 2005. p. 10-15.

Veja a reação no Brasil após o fracasso das negociações da OMC. O Estado de S. Paulo, 29 de julho de 2008. Disponível em :<http://www.estadao.com.br/noticias/economia,vejaa-reacao-no-brasil-apos-o-fracasso-das-negociacoes-da-omc,213916,0.htm>. Acesso em 25 de abril de 2011.

VIGENANI, Tullo; CEPALUNI, Gabriel. A Política Externa de Lula da Silva:A Estratégia da Autonomia pela Diversificação.Contexto Internacional, Rio de Janeiro, vol. 29, n. 2, julho/dezembro 2007.

Venezuela entrou cedo no Mercosul, avaliam especialistas. O Estado de S. Paulo online, 7 de dezembro de 2006. Disponível em:<

http://www.estadao.com.br/arquivo/economia/2006/not20061207p40264.htm> Acesso em: 28 março 2011.

WILLIANSON, John; KUCZYNSKI, Pedro Pablo (orgs). Depois do Consenso de Washington: reformando o crescimento e a reforma na América Latina. São Paulo: Saraiva, 2004.

\section{Sites Consultados:}

CNI:

http://www.cni.org/portal

CEB:

http://www.negociacoesinternacionais.cni.org.br

Funcex:

http://www.funcex.com.br/

Núcleo de Estudos do Empresariado, Instituições e Capitalismo: http://neic.iesp.uerj.br 


\section{ANEXO A - Processo de consulta à Indústria}

\section{Processo de Consulta à Indústria}

A consulta permanente e sistematizada aos empresários define os posicionamentos e as ações da CNI

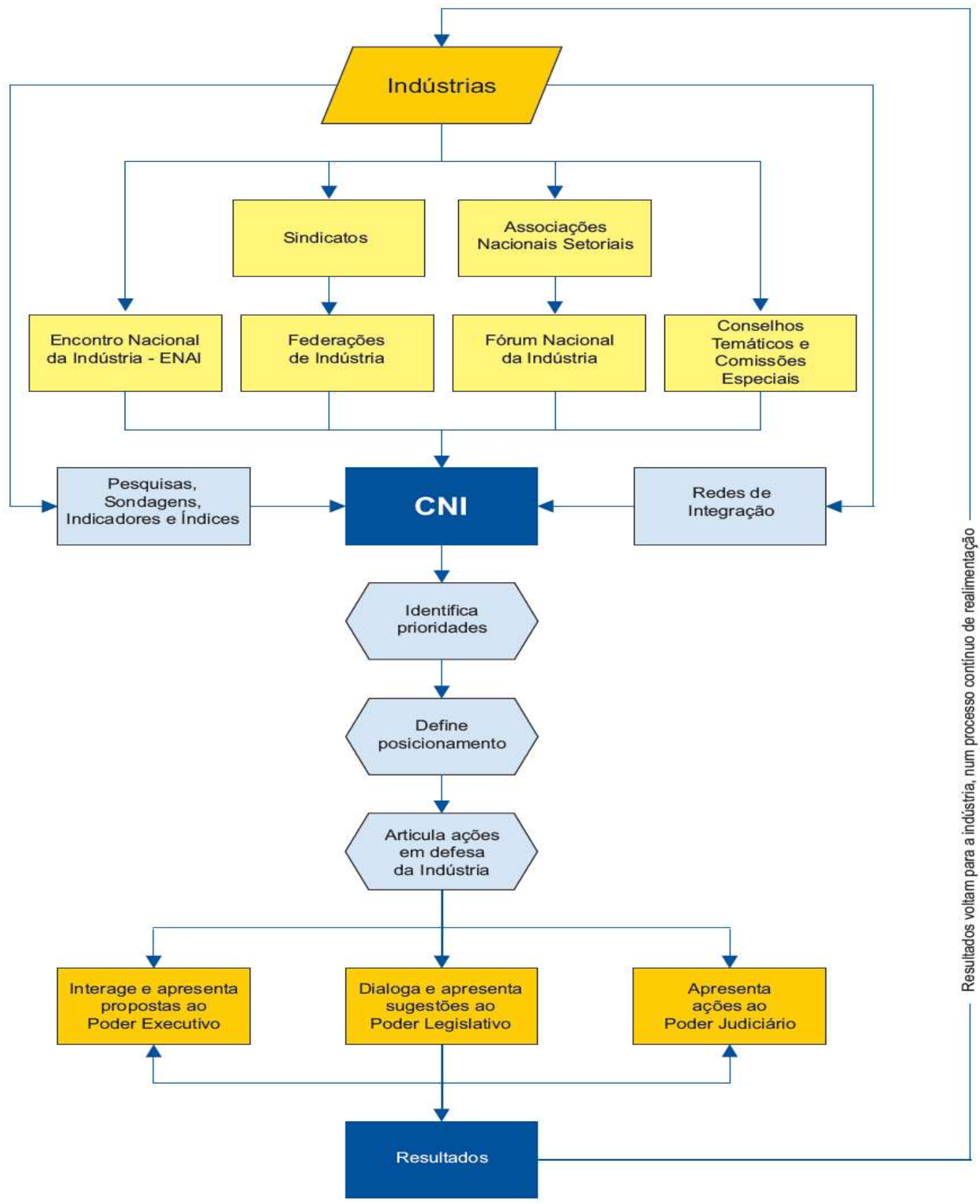

FONTE: CNI/2009. 